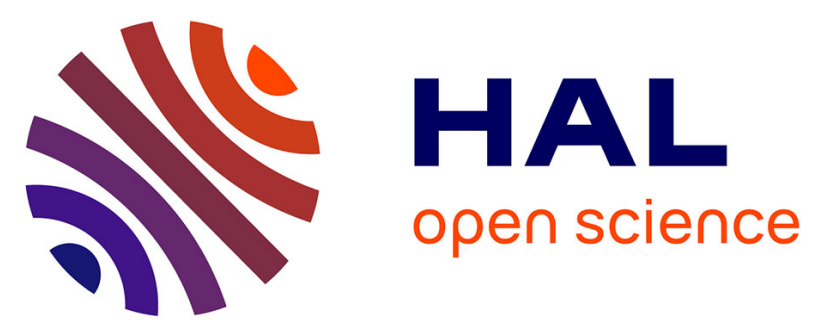

\title{
Dukono, the predominant source of volcanic degassing in Indonesia, sustained by a depleted Indian-MORB
}

Philipson Bani, Giancarlo Tamburello, Estelle F. Rose-Koga, Marco Liuzzo, Alessandro Aiuppa, Nicolas Cluzel, Iwan Amat, Devy Kamil Syahbana, Hendra Gunawan, Marcello Bitetto

\section{To cite this version:}

Philipson Bani, Giancarlo Tamburello, Estelle F. Rose-Koga, Marco Liuzzo, Alessandro Aiuppa, et al.. Dukono, the predominant source of volcanic degassing in Indonesia, sustained by a depleted Indian-MORB. Bulletin of Volcanology, 2018, 80 (1), 10.1007/s00445-017-1178-9 . hal-01664062

\section{HAL Id: hal-01664062 \\ https://hal.uca.fr/hal-01664062}

Submitted on 17 Nov 2020

HAL is a multi-disciplinary open access archive for the deposit and dissemination of scientific research documents, whether they are published or not. The documents may come from teaching and research institutions in France or abroad, or from public or private research centers.
L'archive ouverte pluridisciplinaire HAL, est destinée au dépôt et à la diffusion de documents scientifiques de niveau recherche, publiés ou non, émanant des établissements d'enseignement et de recherche français ou étrangers, des laboratoires publics ou privés. 


\section{Dukono, the predominant source of volcanic degassing in Indonesia, sustained by a depleted Indian-MORB}

Philipson Bani ${ }^{1}$, Giancarlo Tamburello ${ }^{2}$, Estelle F. Rose-Koga ${ }^{1}$, Marco Liuzzo ${ }^{3}$, Alessandro Aiuppa ${ }^{4}$, Nicolas Cluzel ${ }^{1}$, Iwan 5 Amat $^{5}$, Devy Kamil Syahbana ${ }^{5}$, Hendra Gunawan ${ }^{5}$, Marcello Bitetto $^{4}$

1- Université Clermont Auvergne, CNRS, IRD, OPGC, Laboratoire Magmas et Volcans, F-63000 Clermont-Ferrand, France 2- Istituto Nazionale di Geofisica e Vulcanologia, Sezione di Bologna, Via Donato Creti, 12, 40100 Bologna, Italy

3- Istituto Nazionale di Geofisica e Vulcanologia, Sez, Palermo, Via Ugo La Malfa, 15390146 Palermo - Italy

4- Dipartimento di Scienze della Terra e del Mare (DiSTeM), Università di Palermo via archirafi 3690123 Palermo

5- Center for Volcanology and Geological Hazard Mitigation, Jl. Diponegoro No. 57, Bandung, Indonesia

\section{Abstract}

Located on Halmahera island, Dukono is among the least known volcanoes in Indonesia. A compilation of the rare available reports indicates that this remote and hardly accessible volcano has been regularly in eruption since 1933, and has undergone nearly continuous eruptive manifestation over the last decade. The first study of its gas emissions, presented in this work, highlights a huge magmatic volatile contribution into the atmosphere, with an estimated annual output of about $290 \mathrm{kt}$ of SO2, $5000 \mathrm{kt}$ of $\mathrm{H} 2 \mathrm{O}, 88 \mathrm{kt}$ of $\mathrm{CO} 2,5 \mathrm{kt}$ of $\mathrm{H} 2 \mathrm{~S}$ and $7 \mathrm{kt}$ of H2. Assuming these figures are representative of the

20 long-term continuous eruptive activity, then Dukono is the current most prominent volcanic gas discharge point in Indonesia and ranks among the top-ten volcanic $\mathrm{SO} 2$ sources on earth. Combining our findings with other recent volcanic $\mathrm{SO} 2$ flux results, obtained during periodic campaigns at a number of volcanoes with DOAS and UV-Cameras, the SO2 emission budget for Indonesia is estimated at $540 \mathrm{kt} \mathrm{yr}^{-1}$, representing 2-3\% of the global volcanic $\mathrm{SO} 2$ contribution into the atmosphere. This figure should be considered as minimum as gas emissions from numerous other active volcanoes in Indonesia are yet to be evaluated. This voluminous degassing output from Dukono is sustained by a depleted Indian-MORB (I-MORB) mantle source. This latter is currently undergoing lateral pressure from the steepening of the subducted slab, the downward force from the Philippine Sea plate and the westward motion of a continental fragments along the Sorong fault, leading to high fluid fluxes to the surface. Over the course of Dukono eruptive activity, the magma reservoir has changed from a less differentiated source that fed the past voluminous lava flows to a more evolved melt that sustained the current 
ongoing explosive activity.

Keywords: Dukono Volcano, degassing budget, depleted mantle source, magma source evolution

\section{Introduction}

Dukono is a complex volcano with overlapping craters that culminate at $1230 \mathrm{~m}$ above sea level. It is a rather broad and low profile edifice, surrounded by multiple inactive cones. The current activity is hosted in the main central crater of $\sim 700 \mathrm{~m}$ in diameter. Located on the northern part of Halmahera island (Fig. 1), Dukono is the most active volcano in the Maluku region, and perhaps the currently most vigorously active volcano in Indonesia. The historical volcanic activity record, briefly summarized in Table 1, suggests strong eruptive discharges have persisted since 1933. A large eruptive event in 1550 devastated the once known city of Tolo (Data Dasar, 2011; van Padang, 1983). During our visits in July and September 2015, Dukono exhibited nearly continuous eruptive discharge from its two active vents, forming a persistent dense ashy plume up to 200-300 $\mathrm{m}$ above the crater, being dispersed to the north by the prevailing wind. The entire edifice was covered by thick ash deposits (up to a meter at some points) on its flanks.

Despite these remarkable accounts, Dukono is rarely visited, thus very little is known about its manifestations - the main constraints being the remoteness of the edifice and the difficulty of access. We present here the first gas study on Dukono with a focus on the emission budget and the origin of its magma source, using Multicomponent Gas Analyzer System (MultiGAS) and Differential Optical Absorption Spectroscopy (DOAS) measurements, combined with ash-tephra chemistry analysis.

\section{2. Geological setting}

The geodynamic of the Molucca sea is currently dominated by the collision of the Halmahera and Sangihe arcs (Fig. 1). The oceanic lithosphere that existed between the two arcs over last 20 million years has been entirely consumed (Cardwell et al., 1980). According to Hall and Wilson (2000), the Sangihe forearc is presently overriding the Halmahera forearc, while the Halmahera arc itself is thickening by the over-thrusting of its back-arc from the east. The Molucca sea

55 plate that once largely exposed to the surface between Sangihe and Halmahera arcs is now deep in the mantle and sinking further with time (Hall and Wilson, 2000). The currently active volcanoes are formed along the weak points of the entire forearc-arc-backarc section of Halmahera region (Hall and Wilson, 2000).

\section{Methodology}




\section{3-1. MultiGAS}

The Multi-GAS used in this work is a compact portable instrument from UniPa-INGV (as used by Aiuppa et al., 2015). The system simultaneously acquired concentrations of $\mathrm{H} 2 \mathrm{O}, \mathrm{CO} 2, \mathrm{SO} 2, \mathrm{H} 2 \mathrm{~S}$ and $\mathrm{H} 2$ at $0.1 \mathrm{~Hz}$. $\mathrm{H} 2 \mathrm{O}$ and $\mathrm{CO} 2$ were detected by non-dispersive infrared spectroscopy (LI-COR LI-840A; 0-60,000 ppm range), and $\mathrm{SO} 2, \mathrm{H} 2 \mathrm{~S}$ and $\mathrm{H} 2$ via specific electrochemical sensors (respectively, models 3ST/F, EZ3H, and EZT3HYT "Easy Cal"; all from City Technology

65 with calibration range of 0-200 ppm). Powered by a (6 Ah) $12 \mathrm{~V}$ LiPo battery, this lightweight Multi-GAS was placed on the northern part of Dukono's crater (Fig. 1), directly in the plume. Nearly 3 hours of continuous recording was achieved. Acquired data were post-processed using the Ratiocalc program (Tamburello, 2015).

\section{3-2. DOAS measurements}

DOAS measurements were performed from a fixed position about $800 \mathrm{~m}$ north of the active crater (Fig. 1) using a scanning system. The plume drifted to the north during DOAS measurements enabling a vertical scanning across the plume. 67 Spectra were collected per scan with a step angle of $1.8^{\circ}$. The spectrometer used was an Ocean Optics USB2000+ with a spectral range of 290-440 nm and a spectral resolution of 0.5 FWHM. The SO2 column amounts (ppm.m) were retrieved using DOAS calibration and standard analysis procedures (Platt and Stutz, 2008). Reference spectra included in the non-

75 linear fit were obtained by convolving high resolution SO2 (Bogumil et al. 2003) and O3 (Voigt et al. 2001) cross sections with the instrument line shape. A Fraunhofer reference spectrum and Ring spectrum, calculated in DOASIS, were also included in the fit. The total column amount of the plume cross section was then multiplied by the wind mean velocity of 5 $\mathrm{m} \mathrm{s}^{-1}$, obtained from hand-held anemometer on the crater rim, and assumed representative of the plume dispersion speed, to derive the $\mathrm{SO} 2$ emission rate.

80

\section{3-3. Ash-tephra sampling and laboratory analysis}

At about 300 m north of the DOAS measurement point, one meter of layered ash-tephra deposits are exposed to the surface (Fig. 1). Each layer was sampled then analyzed for bulk composition using X-ray Fluorescence (XRF) (Johnson et al. 1999) for major elements and compared to fresh ash fall (July and September 2015) samples. To gain further insights into

85 the magmatic processes and source origin, major and trace elements of olivine, pyroxene and plagioclase hosted melt inclusions were analyzed using Electron Probe Micro Analyzer (EMP) (Cameca SX 100) following standard procedure (e.g. Le Voyer et al., 2008; Cabral et al., 2014). Analytical uncertainties on the samples were typically of $<2 \%$ for $\mathrm{SiO}_{2}, \mathrm{MgO}_{\text {, }}$ and $\mathrm{Al}_{2} \mathrm{O}_{3} ; 3.5 \%$ for $\mathrm{FeO}$ and $\mathrm{CaO} ; 5 \%$ for $\mathrm{K}_{2} \mathrm{O}, \mathrm{TiO}_{2}$, and $\mathrm{Na}_{2} \mathrm{O} ; 10 \%$ for $\mathrm{P}_{2} \mathrm{O}_{5}$; and $30 \%$ for $\mathrm{MnO}(1 \sigma)$. F, S, and $\mathrm{Cl}$ were also measured by EMP with relative uncertainty of $20 \%$ for $\mathrm{S}$ and $30 \%$ for $\mathrm{Cl}$ and $\mathrm{F}$. Trace element measurements were 
carried out using a laser ablation system (193 nm Excimer Resonetics M-50E) associated with an inductively coupled plasma mass spectrometer (Agilent 7500 cs; LA-ICPMS) (e.g. Rose-Koga et al., 2012). The relative $1 \sigma$ standard errors are $<$ $3 \%$ for $\mathrm{Rb}, \mathrm{Sr}, \mathrm{Y}, \mathrm{Zr}, \mathrm{Nb}, \mathrm{Ba}, \mathrm{La}$, and $\mathrm{Ce},<4 \%$ for $\mathrm{Nd},<9 \%$ for $\mathrm{Th}$.

\section{Results}

\section{4-1. Gas composition and emission rate}

The position of the Multi-GAS, on the northern part of Dukono's crater rim (Fig. 1), enhanced direct exposure to eruptive gas discharges but also to heavy ash releases that subsequently saturated the filter after about $1 \mathrm{~h}$ of recording. Results, presented in Figure 2 and Table 2, indicate strong fluctuations in SO2 concentrations, varying from 0.5 to $32 \mathrm{ppm}$, with the alternation of 1-3 minutes of strong releases followed by $0.5-1$ minutes of low background volcanic gas emission.

100 FFT analysis indicates a degassing periodicity of $\sim 3$ minutes. The data-set highlights a H2O-rich gas composition from Dukono, representing a molar proportion of $97 \%$. Other gases detected on Dukono are CO2, H2S and H2 with mean recorded values of 362-400 ppmv, $0.2 \mathrm{ppmv}$ (above atmospheric background) and 1-2 ppmv respectively (Table 2). There is no gas composition change between our two observation periods (in July and September, 2015). All these gases exhibit positive correlations with SO2, implying a common source (Fig. 2). emission rate, obtained after more than two hours of vertical scanning, fluctuates between 400 and $2000 \mathrm{td}^{-1}$ with a mean SO2 flux of $819 \pm 235 \mathrm{t} \mathrm{d}^{-1}$ (Table 3; Fig. 3). The duration of one scan varied between 3 and 6 minutes, depending on the light intensity. The temporal resolution of the DOAS scans is therefore not high enough to resolve the possible degassing periodicity observed with the Multi-GAS. However the difference between the minimum and the maximum emission rates suggests that there are different phases of stronger and lower emissions.

Taking into account the molar ratios of $\mathrm{H} 2 \mathrm{~S} / \mathrm{SO} 2, \mathrm{H} 2 / \mathrm{SO} 2, \mathrm{CO} 2 / \mathrm{SO} 2, \mathrm{H} 2 \mathrm{O} / \mathrm{SO} 2$ (Table 2) we obtain a daily output of $242 \pm$ $69 \mathrm{t}$ of $\mathrm{CO} 2,13 \pm 4 \mathrm{t}$ of $\mathrm{H} 2 \mathrm{~S}, 7 \pm 2 \mathrm{t}$ of $\mathrm{H} 2$ and about $14000 \pm 4000 \mathrm{t}$ of $\mathrm{H} 2 \mathrm{O}$.

\section{4-2. Ash-tephra and melt inclusion composition}

Laboratory analyses result of the ash-tephra samples and melt inclusions are provided in Table 4 and 5. Figure 4 displays the composition changes in terms of alkali versus silica, allowing insights into the source composition. The bulk composition of ash-tephra deposits appear in the junction of trackyandesite and andesite whilst the melt inclusion compositions scattered from basalt to dacite with olivine-pyroxene-hosted melt inclusions plotted in the range of basalt and basaltic-andesite while the plagioclase-hosted melt inclusions spread along the transition line between andesite and 
trachyandesite and even up to differentiated dacitic composition. The volatile content $(\mathrm{S}, \mathrm{Cl}, \mathrm{F})$ in the melt inclusions shows a notable drop of S from around $1100 \mathrm{ppm}$ to $200-400 \mathrm{ppm}$ between olivine-pyroxene and plagioclase hosts whilst $\mathrm{Cl}$ and $\mathrm{F}$ in contrast display relative increase from $600-800$ to $1000-1200 \mathrm{ppm}$ and from 200 to $300-700$ ppm respectively (Fig.5). Trace elements obtained from melt inclusions show elevated large ion lithophile elements (LILE) and light rare elements (LREE) compare to high-field strength elements (HFSEs). $\mathrm{Nb}$ and Ti are below N-MORB concentrations.

\section{Discussion}

\section{5-1. Prominent volcanic gas contribution into the atmosphere}

Due to the remote location and access difficulties, Dukono is one of the least known volcanoes in Indonesia and globally unknown to the scientific community - a paradox since this edifice is among the most active on earth (Table 1)

130 with recurrent eruptive activity since 1933 (GVP Dukono, 2013). In July then in September 2015 (this work), Dukono followed an eruptive manifestation (apparently normal according to local observers) with nearly continuous eruptive discharges from the two active vents in the crater. The mean SO2 flux released from this activity amounts to $0.8 \mathrm{kt}$ per day, which represents a mean annual SO2 output into the atmosphere of $292 \pm 86 \mathrm{kt}$. This figure is much lower than the daily 1.7 kt of $\mathrm{SO}_{2}$ release from Dukono indicated in Carn et al. (2017), based on satellite observations. Although the two $\mathrm{SO}_{2}$ flux

135 approaches are not exactly equivalent, since we are measuring the emission rates directly whilst satellites output an $\mathrm{SO}_{2}$ atmospheric burden, the two results should be at least comparable (Bani et al., 2009a; 2009b) or lower for the Ozone Monitoring Instrument (OMI) onboard Aura satellite (McCormick et al., 2012; Bani et al., 2016). This satellite-based high $\mathrm{SO}_{2}$ flux derived from a longer observation period (several years) but might be biased by over-sampling more vigorous (and most visible) explosive periods (Carn et al., 2016). The OMI estimation for July 13, 2015 is $0.02 \mathrm{kt}$ which is an order of

140 magnitude lower than our DOAS result for that same day (Fig. 3). Other DOAS measurements in the future are required to refine these first estimates, however our finding suggests that Dukono volcanic gas contribution into the atmosphere is higher than any other known persistent volcanic degassing source in Indonesia, measured with modern tools (DOAS and UV-Camera), including Merapi (18 - $160 \mathrm{kt} \mathrm{yr}^{-1}$; Surono et al., 2012), Krakatau (70 kt yr ${ }^{-1}$; Bani et al., 2015), Kawah Ijen (64 kt yr ${ }^{-1}$; Gunawan et al., 2016), Bromo (60 kt yr ${ }^{-1}$; Aiuppa et al., 2015), Semeru (20 - $70 \mathrm{kt} \mathrm{yr}^{-1}$; Smekens et al., 2015),

145 Sirung (17 kt yr-1; Bani et al. (in press)) and Papandayan (0.5 kt yr ${ }^{-1}$; Bani et al., 2013). If put in the context of the well known compilation of Andres and Kasgnoc (1998), the Dukono's SO2 contribution into the atmosphere is comparable to that of Kilauea, in the top ten of the volcanic degassing sources worldwide. Combining together the above SO2 emission data from 7 Indonesian volcanoes, one obtains a minimum annual volcanic SO2 output of 540 kt into the atmosphere, representing 2-3\% of the global volcanic emission budget (15-21 Tg; Halmer et al., 2002). This figure is much higher than 
the $100 \mathrm{kt}$ of SO2 emission budget provided by Andres and Kasgnoc (1998) or $120 \mathrm{kt}$ in Fischer (2008) for the whole Indonesian volcanoes. Knowing that there are 127 active volcanoes in Indonesia, it is thus evident that these past figures are strongly underestimating the volcanic degassing budget from this archipelago. Indeed, the most recent estimation provided by Carn et al. (2017) based on satellite observations, indicates a much higher release with an annually $\mathrm{SO}_{2}$ emission budget of around $2200 \mathrm{kt}$, representing about $10 \%$ of the global volcanic $\mathrm{SO}_{2}$ contribution into the atmosphere $(23 \mathrm{Tg}$; Carn et al.,

155 2017). However this figure still requires ground-based validation in Indonesia. Note also that only 16 out of 127 volcanoes are considered in this latter work. .

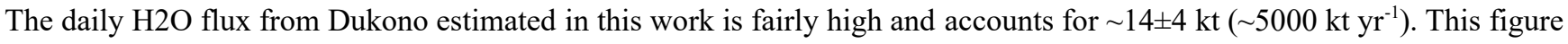
derives directly from the $\mathrm{H} 2 \mathrm{O}$-rich signature of volcanic gas vented from Dukono. Indeed, the $\mathrm{H} 2 \mathrm{O}$ molar proportion is 97\% (Table 2), which falls in the upper domain for arc volcanic gases (Fischer, 2008) and is comparable, to, e.g., Bromo

160 (H2O mol. 95\%; Aiuppa et al., 2015) or Yasur (H2O mol. 98\%; Metrich et al., 2011). Note that the H2O flux likely constitutes higher bound estimate since a meteoric water contribution to the Dukono degassing system cannot be ruled out. However the fairly strong correlation between $\mathrm{H} 2 \mathrm{O}$ and the other gases, including $\mathrm{CO} 2, \mathrm{SO} 2, \mathrm{H} 2 \mathrm{~S}$ and $\mathrm{H} 2$ (Fig. 2), suggests a primarily magmatic $\mathrm{H} 2 \mathrm{O}$ source. The high water proportion (4-5 wt\%) calculated by weight difference from melt inclusions and its positive correlation with S content (Table 4; Fig.5) supports the magmatic origin of $\mathrm{H} 2 \mathrm{O}$. three better known Indonesian volcanoes, including Bromo, Papandayan and Merapi, where CO2 represents 3.5 mol. \% (Aiuppa et al., 2015), 2.9 mol. \% (Giggenbach, 1996) and 4.7-5.6 mol. \% (Giggenbach et al., 2001) in their respective volcanic gas. But on Dukono, the $\mathrm{CO} 2$ constitutes the $3 \mathrm{rd}$ most abundant gas composition with only 0.7 mol. \% behind $\mathrm{H} 2 \mathrm{O}$ and $\mathrm{SO} 2$ (1.6 mol. \%). Using the $\mathrm{CO} 2 / \mathrm{SO} 2$ ratio of (Table 2), we derive an annual $\mathrm{CO} 2$ emission rate of $88 \mathrm{kt}$ from

170 Dukono. Such release represents $\sim 0.03 \%$ of the global volcanic CO2 emission budget (271 Mt yr ${ }^{-1}$; Burton et al., 2013) into the atmosphere. Further investigations are still required to constrain this low $\mathrm{CO}_{2}$ signature at Dukono, however, using the $\mathrm{CO}_{2} / \mathrm{SO}_{2}$ and $\mathrm{H}_{2} \mathrm{~S} / \mathrm{SO}_{2}$ ratios of 0.5 and 0.03 respectively (Table 2), one can derive a $\mathrm{CO}_{2} / \mathrm{S}_{\mathrm{T}}$ ratio of 0.4 , corresponding to group 2 volcanoes in the Aiuppa et al. (2017) classification, suggesting a de-volatilized slab source.

Another gas species quantified in the plume of Dukono is the H2. It constitutes 0.4 molar $\%$ of the emitted gas and 175 a $\mathrm{H} 2 / \mathrm{SO} 2$ molar ratio of 0.3. Combining this latter ratio with the $\mathrm{SO} 2$ flux, we estimate an annual $\mathrm{H} 2$ emission budget of $2.5 \pm 0.7 \mathrm{kt}$ (Table 2). To date, still very few measurements have captured the molecular hydrogen in the plume, thus much is yet required to provide acceptable estimation of global volcanic H2 output into the atmosphere. In any case, Dukono is a significant source of molecular hydrogen into the atmosphere.

The H2S, also measured in Dukono plume, has a fairly strong correlation with other gas species (Fig. 2). It 
constitutes 0.05 molar \% of Dukono gas composition. The mean $\mathrm{H} 2 \mathrm{~S} / \mathrm{SO} 2$ ratio is 0.03 , which gives an annual output estimation of $13 \pm 4 \mathrm{kt}$, representing $0.03-0.8 \%$ of the global volcanic H2S output (1500-37100 kt; Halmer et al., 2002) into the atmosphere.

The quantification of Indonesian volcanic volatile contributions into the atmosphere still remains sparse as the emissions from other volcanoes are yet to be measured. However, Dukono is clearly a strong volcanic volatile contributor into the atmosphere, at the global scale. Taken into account its long eruptive manifestation, as highlighted by Carn et al. (2016), it is plausible that Dukono may constitute the biggest volcanic degassing source in Indonesia.

\section{5-2. A depleted I-MORB source and high fluid fluxing}

The trace elements in melt inclusions (this work) normalized to normal mid-ocean ridge basalt (N-MORB) (Sun and McDonough, 1989) point out elevated ratios of large ion lithophile elements (LILEs) and light rare elements (LREEs) to the high-field strength elements (HFSEs) (Fig. 6A). Such patterns observed at Dukono are typical of subduction zones in which the mantle wedge has been contaminated by fluids released from the subduction slab (McCulloch and Gamble, 1991; Davidson, 1996; Marpherson et al., 2003).

It is known that during slab de-volatilization, $\mathrm{Nb}$ and $\mathrm{Zr}$ are relatively immobile. The MORB sources display a restricted range of $\mathrm{Zr} / \mathrm{Nb}$ (Fig. 6A) (e.g., Elliott et al., 1997), whilst at subduction zones, $\mathrm{Zr} / \mathrm{Nb}$ can vary significantly (e.g., McCulloch and Gamble, 1991), as seen at Halmahera (Fig. 6B). A high $\mathrm{Zr} / \mathrm{Nb}$ cannot be generated by MORB-source (Woodhead et al., 1993). Instead, it characterizes mantle that has previously lost a basaltic melt fraction, leaving behind a source that is more depleted in highly incompatible elements, such as $\mathrm{Nb}$ (Macpherson et al., 2003). It is thus likely that this high $\mathrm{Zr} / \mathrm{Nb}$ on Dukono derived from a depleted mantle wedge (Fig. 6B) in agreement with the changes in $\mathrm{Zr} / \mathrm{Nb}$ ratios along the Halmahera arc, from N-MORB range (low $\mathrm{Zr} / \mathrm{Nb}$ ) at Obi to an evolved mantle wedge source at Bacan and central Halmahera (Fig.1; Fig. 6A; Macpherson et al., 2003).

A refractory source requires high fluid fluxes to lower the solidus and assist the melting process, therefore a high $\mathrm{Zr} / \mathrm{Nb}$ ratio suggests important fluid fluxing. Further, given the high mobility of $\mathrm{Ba}$, any incoming fluid into a depleted mantle source will produce a broad correlation between $\mathrm{Zr} / \mathrm{Nb}$ and Ba/Nb (Fig. 6B) (e.g., Keppler, 1996; Macpherson et al., 2003). The high ratios and strong correlation between $\mathrm{Zr} / \mathrm{Nb}$ and $\mathrm{Ba} / \mathrm{Nb}$ obtained at Dukono (Fig.6B) thus support the idea of high fluid fluxes that sustain volcanic activity. The steepening of the subducted slab, the downward force from the Philippine sea plate and the westward motion of a continental fragments along the Sorong fault (Fig.1), are the main tectonic motions that can enhance mantle wedge compression beneath Halmahera (Macpherson et al., 2003; Elliott et al., 1997) leading to high fluid fluxes. These motions were evidenced in the evolution of $\mathrm{Zr} / \mathrm{Nb}$ and $\mathrm{Ba} / \mathrm{Nb}$ ratios at Halmahera 
between Neogene and Quaternary (Macpherson et al., 2003). Indeed the ratios decline and shift toward the enriched IMORB composition (Fig.6B) (Dosso et al, 1988; Le Roex et al., 1989) suggesting a progressive change from a depleted to enriched mantle source. Further, the steepening of the slab increases the effects of slab rollback in the mantle, leading to an increasing flux of recycled sediment as highlighted by the increase of ${ }^{208} \mathrm{~Pb} /{ }^{204} \mathrm{~Pb}$ at a given point of ${ }^{206} \mathrm{~Pb} /{ }^{204} \mathrm{~Pb}$ (Fig.6D, Macpherson et al., 2003). Note here that the scatter plot of ${ }^{207} \mathrm{~Pb} /{ }^{204} \mathrm{~Pb}$ and ${ }^{206} \mathrm{~Pb} /{ }^{204} \mathrm{~Pb}$ ratios for Halmahera volcanic rocks indicate Indian-MORB source (e.g., Macpherson et al., 2003).

\section{5-3. Evolved magma source}

During fractional crystallization, melt inclusions, trapped in series of minerals, behave as closed and isolated systems, retaining much of the original composition of the melt, including their volatile content. Therefore, they constitute an ideal tool to shed light on the source of the magma and on igneous processes (e.g., Schiano, 2003; Cannatelli et al., 2016). In that respect, the melt inclusion results obtained in this work (Fig. 4, Table 4) clearly trace back the fractional crystallization of Dukono magmatic source. The bulk chemistry of the ash-tephra deposits (Table 4), plotted in the total alkali-versus-silica (TAS) and K2O-silica diagrams (Fig. 4), indicate andesitic to tranchyandesitic magma composition with medium to relatively high-K content. Olivine-pyroxene-plagioclase-hosted melt inclusions show a wider range of The plagioclase content shows a clear evolution with increasing $\mathrm{SiO}_{2}$, from Ca-rich to Na-rich composition (Fig. 4). Such change generally reflect the continuous branch of Bowens's reaction series where calcium-rich plagioclase crystallizes first then progressively evolves to sodium-rich with the cooling melt (e.g., Monroe and Wicander, 2014). The melt inclusion volatiles show a progressive increase of $\mathrm{Cl}$ and $\mathrm{F}$, from 600 to $1000 \mathrm{ppm}$ and from $200 \mathrm{ppm}$ to $>200-700 \mathrm{ppm}$ respectively

230 (Fig. 5), implying incompatible behavior during crystal fractionation (Aiuppa et al., 2009). Fluorine has a high affinity for silicate melts, thus it may progressively enriched in magma through time as magmatic differentiation takes place (Sawyer and Oppenheimer, 2006). Sulfur concentrations in Dukono inclusions show a notable drop from 1100 to $300 \mathrm{ppm}$ suggesting sulfur lost, likely through open-system degassing. All those observations indicate that the magmatic source beneath Dukono has evolved over time and that the current ongoing explosive activity is sustained by a more differentiated magma, which contrast with the voluminous lava outputs reported in the past (1550 and 1933; Table 1) likely sourced by a less viscous and less differentiated melt source.

\section{Conclusion}

Dukono is the most active volcano in Maluku and likely the most vigorous edifice in Indonesia with continuous 
and long eruptive manifestations. But due to its isolation and access difficulties, very little is known about its activity. The first measurements of its magmatic volatile contribution into the atmosphere, presented in this work, indicate that Dukono is the biggest volcanic SO2 contributor in Indonesia and ranks among the top ten volcanic SO2 sources on earth. Each year about $290 \mathrm{kt}$ of $\mathrm{SO} 2$ are released into the atmosphere from this volcano, a huge contribution that significantly increases the Indonesia archipelago annual volcanic SO2 budget from $100 \mathrm{kt}$ (Andres and Kasgnoc, 1998) to $540 \mathrm{kt}$ (including all recent published measurement results). This new Indonesian SO2 emission budget constitutes 2-3\% of the global volcanic $\mathrm{SO} 2$

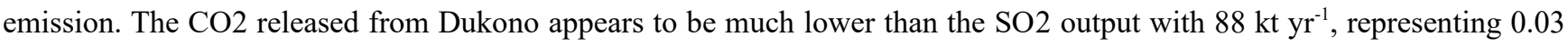
$\%$ of global volcanic $\mathrm{CO} 2$ budget. Dukono also releases annually about $5000 \mathrm{kt}$ of H2O, $41 \mathrm{kt}$ of H2S, and $0.4 \mathrm{kt}$ of $\mathrm{H} 2$ into the atmosphere.

The current degassing regime on Dukono is maintained by the ongoing explosive activity, enhanced by a differentiated magmatic source. Indeed, as evidenced in this work, the melt source has changed over the course of Dukono eruptive activity, evolving from a less viscous source that fed the past voluminous lava flows to a silica-rich melt behind the current ongoing explosive activity. In parallel to this differentiated melt source, trace element analyses highlight a depleted IndianMORB in the mantle wedge beneath Dukono, a paradox behind the high degassing of Dukono. However, as highlighted in this work, the steepening of the subducted slab, the downward force from the Philippine sea plate and the westward motion of a continental fragments along the Sorong fault may develop sufficient pressure on the mantle wedge to enable high fluid fluxes to the surface.

\section{Acknowledgment}

This work was achieved under the collaboration between Center of Volcanology and Geological Hazards (CVGHM) and Institut de Recherche pour le Développement (IRD) under the JEAI-Commission program. We gratefully acknowledge the technical assistance from Dukono Observatory. We thank B. McCormick and an anonymous reviewer for useful comments and suggestions.

This is a Laboratory of Excellence ClerVolc contribution number 273.

\section{References}

Aiuppa A, Baker DR., Webster JD (2009) Halogens in volcanic systems. Chem. Geol., 263, 1-18

Aiuppa A, Bani P, Moussallam Y, Di Napoli R, Allard P, Gunawan H, Hendrasto M, Tamburello G (2015) First determination of magma-derived gas emissions from Bromo volcano, eastern Java (Indonesia). J. Volcanol. Geotherm. 
Res. 304, 206-213

Aiuppa A, Fischer TP, Plank T, Robidoux P, Di Napoli R (2017) Along-arc, inter-arc and arc-to-arc variations in volcanic gas $\mathrm{SO}_{2} / \mathrm{S}_{\mathrm{T}}$ ratios reveal dual source of carbon in arc volcanism. Earth-Science Reviews, 168, 24-47

Andres RJ and Kasgnoc AD (1998) A time-average inventory of subaerial volcanic sulfur emissions. J. Geophys. Res., 103, $25251-25261$

Bani P, Join J-L, Cronin SJ, Lardy M, Rouet I, Garaebiti E (2009a) Characteristics of the summit lakes of Ambae volcano and their potential for generating lahars. Nat. Hazards Earth Syst. Sci., 9, 1471-1478

Bani, P., Oppneheimer, C., Tsanev, V.I., Carn, S.A., Cronin, S.J., Crimp, R., Charley, D., Lardy, M., Robert, T.R. (2009b) Surge in sulphur and halogen degassing from Ambrym volcano, Vanuatu. Bull. Volcanol., 71(10), 1159-1168, doi:10.1007/s00445-009-0293-7.

Bani P, Surono, Hendrasto M, Gunawan H, Primulyana S (2013) Sulfur dioxide emissions from Papandayan and Bromo, two Indonesian volcanoes. Nat. Hazards Earth Syst. Sci., 13, 2399-2407, doi:10.5194/nhess-13-2399-2013

Bani P, Normier A, Bacri C, Gunawan H, Hendrasto M, Surono, Tsanev V (2015) First evaluation of sulfur dioxide degassing from Anak Krakatau volcano, Indonesia. J. Volcanol. Geotherm. Res. 302, 237-241.

Bani P, Boudon G, Balcone-Boissard H, Delmelle P, Quiniou T, Lefèvre J, Garaebiti Bule E, Shinohara H, Lardy M (2016) The 2009-2010 eruption of Gaua volcano (Vanuatu archipelago): eruptive dynamics and unsuspected strong halogens source. J. Volcanol. Geotherm. Res., 322, 63-75

Bani P, Alfianti H, Aiuppa A, Oppenheimer C, Sitinjak P, Tsanev V, Saing UB (2017) First study of heat and gas buget for Sirung volcano, Indonesia. Bull Volcanol 79:60, DOI 10.1007/s00445-017-1142-8

Bogumil K, Orphal J, Homann T, Voigt S, Spietz P, Fleischmann OC, Vogel A, Harmann M, Kromminga H, Bovensmann H, Frerick J, Burrows JP (2003) Measurements of molecular absorption spectra with SCIAMACHY preflight model: instrument characterization and reference data for atmospheric remote sensing in the $230-2380 \mathrm{~nm}$ region. J. Photochem. Photobiol., A 157, 167-184

Burton MR, Sawyer GM, Granieri D (2013) Deep Carbon Emissions from Volcanoes. Review in Mineralogy \& Geochemistry $75,323-354$

Cabral RA, Jackson MG, Koga KT, Rose-Koga EF, Hauri EH, Whitehouse MJ, Price AA, Day JMD, Shimizu N and Kelley KA (2014) Volatile cycling of $\mathrm{H} \mathrm{2O}, \mathrm{CO} 2, \mathrm{~F}$, and $\mathrm{Cl}$ in the HIMU mantle: A new window provided by melt inclusions from oceanic hot spot lavas at Mangaia, Cook Islands: Geochemistry Geophysics Geosystems, v. 15, no. 11, p. 44454467, doi: 10.1002/2014GC005473

Cannatelli C, Doherty AL, Esposito R, Lima A, De Vivo B (2016) Understanding a volcano through a droplet: A melt inclusion approach. J. Geochem. Expl. 171, 4-19

Cardwell RK, Isacks BL, Karig DE (1980) The spatial distribution of earthquakes, focal mechanism solutions and subducted lithosphere in the Philippine and northeast Indonesian islands. American Geophysical Union, Geophysical Monographs, 23, 1-36

Carn SA, Clarisse L, Prata AJ (2016) Multi-decadal satellite measurements of global volcanic degassing. J. Volcanol. Geotherm. Res. 311, 99-134

Carn SA, Fioletov VE, McLinden CA, Li C, Krotkov NA (2017) Adecade of global volcanic $\mathrm{SO}_{2}$ emissions measured from space. Sci. Rep. 7, 44095; doi:10.1038/srep44095

Data Dasar Gunung api Indonesia (2011) Kementerian Energi dan Sumber daya Mineral, Badan Geologi. edisi kedua, 401410 
Davidson JP (1996) Deciphering mantle and crustal signatures in subduction zones. In: Bebout, G.E., Scholl, D.W., Kirby, S.H., platt, J.P. (eds), Subduction: Top to Bottom. American Geophysical Union Monograph, 96, 251-262

Dosso L, Bougault H, Beuzart P, Calcez JY, Joron JL (1988) The geochemical structure of the Southeast Indian Ridge. Earth and Planetary Science Letters, 88, 47-59

Elliott T, Plank T, Zindler A, White W, Bourdon B (1997) Element transport from slab to volcanic front at the Mariana arc. Journal of Geophysical Research, 102, 14991-15019

Fischer TP (2008) Fluxes of volatiles (H2O, CO2, N2, Cl, F) from arc volcanoes. Geochem. J. 42, 21-38

Giggenbach WF (1996) Chemical composition of volcanic gases. IAVCEI-UNESCO: Monitoring and Mitigation of Volcano Hazards (Tilling, R. and Scarpa, R., eds.), Springer-Verlag, Berlin Heidelberg

Giggenbach WF, Tedesco D, Sulisiyo Y, Caprai A, Cioni R, Favara R, Fischer TP, Hirabayashi J, Korzhinsky M, Martini M, Menyailov I and Shinohara H (2001) Evaluation of results from Forth and Fifth IAVCEI Field Workshop on Volcanic Gases, Vulcano Island, Italy and Java, Indonesia. J. Volcanol. Geotherm. Res. 108, 283-02

Global Volcanism Program (2013) Dukono (268010) in Volcanoes of the World, v. 4.5.4. Venzke, E (ed.). Smithsonian Institution. $\quad$ Downloaded $20 \quad$ Mar 2017 (http://volcano.si.edu/volcano.cfm?vn=268010). http://dx.doi.org/10.5479/si.GVP.VOTW4-2013

Gunawan H, Caudron C, Pallister J, Primulyana S, Christenson B, McCausland W, Van Hinsberg V, Lewicki J, Rouwet D, Kelly P, Kern C, Werner C, Johnson JB, Utami SB, Syahbana DK, Saing U, Suparjan, Purwanto BH, Sealing C, Cruz MM, Maryanto S, Bani P, Laurin A, Schmid A, Bradley K, Agung Nandaka IGM, Hendrasto M (2016) New insights into Kawah Ijen's volcanic system from the wet volcano workshop experiment. Geological Society, London, Special Publications, 437, doi:10.1144/SP437.7

Hall R, Wilson MEJ (2000) Neogene sutures in eastern Indonesia. J. Asian Earth Sciences, 18, 781-808

Halmer MM, Schmincke HF and Graf HF 2002 The annual volcanic gas input into the atmosphere, in particular into the stratosphere: a global data set for the past 100 years, J. Volcanol. Geoth. Res., 115, 511-528

Johnson DM, Hooper PR, Conrey RM (1999) XRF Analysus of Rocks and Minerals for Major and Trace Elements on a Single Low Dilution Li-tetraborate Fused Bead. JCPDS-International Centre for Diffraction Data

Keppler H (1996) Constraints from partitioning experiments on the composition of subduction zone fluids. Nature, 380, $237-240$

Le Roex AP, Dick HJB, Fisher RL (1989) Petrology and geochemestry of MORB from $25^{\circ} \mathrm{E}$ to $46^{\circ} \mathrm{E}$ along the Southwest Indian Ridge: Evidence for constrasting styles of mantle enrichment. Journal of Petrology, 30, 947-986

Le Voyer M, Rose-Koga EF, Laubier M and Schiano P (2008) Petrogenesis of arc lavas from the Rucu Pichincha and Pan de Azucar volcanoes (Ecuadorian arc): Major, trace element, and boron isotope evidences from olivine-hosted melt inclusions: Geochemistry Geophysics Geosystems, v. 9, no. 12, doi: 10.1029/2008GC002173

Macpherson CG, Forde EJ, Hall R, Thirlwall MF (2003) Geochemical evolution of magmatism in an arc-arc collision: the Halmahera and Sangihe arcs, eastern Indonesia. In: Larter, R.D., Leat, P.T. (eds), Intra-Oceanic Subduction Systems: Tectonic and Magmatic Processes. Geological Society, London, Special Publications, 219, 207-220

McCormick BT, Edmonds M, Mather TA and Carn SA (2012) First synoptic analysis of volcanic degassing in Papua New Guinea, Geochem. Geophys. Geosyst., 13, Q03008, doi:10.1029/2011GC003945

McCulloch MT, Gamble JA (1991) Geochemical and geodynamical constraints on subduction zone magmatims. Earth and Planetary Science Letters, 102, 358-374

Metrich N, Allard P, Aiuppa A., Bani P, Bertagnini A, Shinohara H, Parello F, Di Muro A, Garaebiti E, Belhadj O, Massare 
D (2011) Magma and volatile supply to post-collapse renewed volcanism and block resurgence in Siwi caldera (Tanna,Vanuatu arc). Journal of Petrology. doi: 10.1093/petrology/egr019

Monroe JS, Wicander R (2014) The Changing Earth, Exploring Geology and Evolution, $7^{\text {th }}$ edition, Cengage Learning, Stamford, USA

Platt U, Stutz J (2008) Differential Optical Absorption Spectroscopy, Principles and Applications, Springer, 597 pp

Rose-Koga EF, Koga K, Schiano P and Le Voyer M (2012) Mantle source heterogeneity for South Tyrrhenian magmas revealed by $\mathrm{Pb}$ isotopes and halogen contents of olivine-hosted melt inclusions: Chemical Geology, v. 334, p. 266-279

Saing UB, Bani P, Kristianto (2014) Ibu volcano, a center of spectacular dacite dome growth and long-term continuous eruptive discharges. Journ. Volcanol. Geotherm. Res, 282, 36-42

Sawyer GM and Oppenheimer C (2006) Chapter 5: Volcanic Fluorine Emissions: Observations by Fourier Transform Infrared Spectroscopy. Advances in Fluorine Science, v. 1, p.165-185. doi:10.1016/S1872-0358(06)01005-0

Schiano P (2003) Primitive mantle magmas recorded as silicate melt inclusions in igneous minerals: Earth-Science Reviews, v. 63, no. 1-2, p. 121-144, doi: 10.1016/S0012-8252(03)00034-5

Smekens JF, Clarke AB, Burton MR, Harijoko A, Wibowo HE (2015) SO2 emissions at Semeru volcano, Indonesia: characterization and quantification of persistent and periodic explosive activity. J. Volcanol. Geotherm. Res. 300, 121128

Shinohara H (2008) Excess degassing from volcanoes and its role on eruptive and intrusive activity, Rev. Geophys., 46, RG4005, doi:10.1029/2007RG000244

Sun S-S, McDonough WF (1989) Chemical and isotopic systematics of oceanic basalts: In: Saunders, A.D. and Norry, M.J., (eds), Magmatism in the Ocean Basins. Geological Society, London, Special Publications, 42, 313-345

Surono et al (2012) The 2010 explosive eruption of Java's Merapi volcano-a '100-year' event. J. Volcanol. Geotherm. Res. 241-242 (2012), 121-135. http://dx.doi.org/10.1016/j.jvolgeores.2012.06.018

Tamburello G (2015) Ratiocalc: Software for processing data from multicomponent volcanic gas analyzers, Computers and Geosciences, 82, pp. 63-67

Van Padang N (1983). History of volcanology in the East Indies. Scripta Geol. 71, 1-76

Voigt S, Orphal J, Bogumil K, Burrows JP (2001) The temperature dependence (203-293 K) of the absorption crosssections of $\mathrm{O} 3$ in the 230-850 nm region measured by Fourier-transform spectroscopy. J. Photochem. Photobiol., A 143, $1-9$

Woodhead JD, Eggins S, Gamble JA (1993) High field strenght and transition element systematics in island arc and backarc basin basalt: evidence for multi-phase melt extraction and a depleted mantle wedge. Earth and Planetary Science Letter, 114, 491-504

\section{Captions}

Table 1. Brief chronology of Dukono volcanic activity.

Table 2. Dukono gas composition, mean concentrations, gas ratios and fluxes. 
Table 3. $\mathrm{SO}_{2}$ flux results obtained from scanning DOAS.

Table 4. Composition of Dukono bulk ash-tephra deposits and major to trace elements content of olivine-pyroxeneplagioclase-hosted melt inclusion

Figure 1. Dukono volcano located on Halmahera island, east Indonesia. The crater hosts 2 active vents (A). The collision of the Halmahera and Sangihe arcs is highlighted in cross section a-a', adapted from Hall and Wilson (2000) (B). The measurement positions of the scanning DOAS and MutiGAS as well as the ash-tephra sampling points are indicated in (A). Pictures on the right provide an insight into Dukono crater (1), the ashy plume above the crater (2) and a strong eruptive discharge observed $10 \mathrm{~km}$ from the crater (3).

Figure 2. Scatter plots of $\mathrm{SO}_{2}$ vs $\mathrm{H}_{2}(\mathrm{~A}), \mathrm{CO}_{2}(\mathrm{~B}), \mathrm{H}_{2} \mathrm{O}(\mathrm{C})$ and $\mathrm{H}_{2} \mathrm{~S}$ (D); the correlation between $\mathrm{H}_{2} \mathrm{O}$ and $\mathrm{CO}_{2}$ is displayed (E). The $\mathrm{SO}_{2}$ fluctuation over the recording period (F) with the corresponding FFT result $(\mathrm{G})$ indicating a degassing periodicity of $\sim 3$ minutes.

Figure 3. $\mathrm{SO}_{2}$ scanning profiles across the plume; the mean profile is in red (above). Fluctuation of $\mathrm{SO}_{2}$ flux over the DOAS scanning period (below). The sub-image displays the result obtained by OMI (Ozone Monitoring Instrument) for the same date as the DOAS measurement (July 13, 2015). This OMI image was acquired during DOAS measurements. The time difference between Universal Time Coordinated and Halmahera is $9 \mathrm{~h}$.

Figure 4. Ash-tephra and melt inclusion samples placed into the total alkali and $\mathrm{K}_{2} \mathrm{O}$ versus $\mathrm{SiO}_{2}$ plots indicate andesitetrachyandesite with medium to high-K bulk composition (red cross), basaltic andesite olivine (blue circle), basalt to basaltic andesite pyroxene (blue asterisk) and andesite-trachyandeiste plagioclase (blue square). This latter shows an extend to higher $\mathrm{SiO}_{2}$. White circles indicate Ibu volcano bulk composition changes for comparison. The subplot (on the $\mathrm{K}_{2} \mathrm{O}-\mathrm{SiO}_{2}$ plot) denotes the evolution of plagioclase composition, from high $\mathrm{Ca}$ low $\mathrm{Na}$ (anorthite) to high $\mathrm{Na}$ low $\mathrm{Ca}$ (albite). The pictures on the right are the ash-tephra layer sampled and analyzed. The detail composition of the layers (A, B, C, 1, 2, 3, 4, 5) are provided in Table 3. The white circles denote the melt composition change observed on Ibu, the closest volcano to Dukono (Saing et al., 2014)

Figure 5. Volatile contents in melt inclusions (A). The $\mathrm{Cl}$ concentration shows a progressive increase with the increasing $\mathrm{SiO}_{2}$ (green triangle). $\mathrm{F}$ evolved from a relatively stable concentration in low $\mathrm{SiO}_{2}$ melt (black cross) to higher content with a more differentiated melt. The $\mathrm{S}$ highlights a notable drop with the increasing $\mathrm{SiO}_{2}$, similar to the calculated $\mathrm{H}_{2} \mathrm{O}$. Incompatible element abundance in the olivine-pyroxene-plagioclase-hosted melt inclusions, normalized to N-MORB (B).

Figure 6. (A) $\mathrm{Zr} / \mathrm{Nb}$ vs $\mathrm{MgO}$ of Dukono (this work, red asterisk) compared to Obi, Central Halmahera and Becan (data from Macpherson et al., 2003) (B); $\mathrm{Ba} / \mathrm{Nb}$ vs $\mathrm{Zr} / \mathrm{Nb}$ of Dukono (this work, red asterisk) compared to central Halmahera and I-MORB (data from Macpherson et al., 2003) (C). Note that Macpherson et al. (2003) observed an evolution in melt composition on Halmahera between Neogene and Quaternary. (C) The Halmahera ${ }^{208} \mathrm{~Pb} /{ }^{204} \mathrm{~Pb}$ and ${ }^{206} \mathrm{~Pb} /{ }^{204} \mathrm{~Pb}$ rocks plotted on Indian MORB. Note the increase in the ${ }^{208} \mathrm{~Pb} /{ }^{204} \mathrm{~Pb}$ and ${ }^{206} \mathrm{~Pb} /{ }^{204} \mathrm{~Pb}$ ratios between Neogene and Quaternary 
(data from Mcpherson et al., 2003). 
Table 1.

\begin{tabular}{|c|c|}
\hline 1550 & $\begin{array}{l}\text { Large eruption spilling out huge amount of lava to the coast, destroying the once known Tolo city } \\
\text { (van Padang, 1983). }\end{array}$ \\
\hline 1719 & Eruptive activity on the eastern flank (GVP, 2013) \\
\hline 1861-1869 & $\begin{array}{l}\text { Eruption at the main crater. Vegetation close to summit was destroyed by fire triggered by the } \\
\text { eruption (Data Dasar, 2011). }\end{array}$ \\
\hline 1901 & $\begin{array}{l}\text { Eruption occurred at the main crater whilst strong fumarole activity observed on the surrounding } \\
\text { cones (Data Dasar, 2011). }\end{array}$ \\
\hline Aug. 1933 & $\begin{array}{l}\text { Strong eruption with large lava flow to the north and ash fall up to } 15 \mathrm{~km} \text { northeast of the volcano } \\
\text { (Data Dasar, 2011). }\end{array}$ \\
\hline 1945 & Eruption leading to ash fall on Tobelo city, situated $15 \mathrm{~km}$ northeast of the volcano \\
\hline Jul. 1946 & $\begin{array}{l}\text { Eruption generating ash fall on Morotai island, } 60 \mathrm{~km} \text { northeast of Dukono. At Tobelo, } 1 \mathrm{~cm} \text { of ash } \\
\text { fall was observed (Data Dasar, 2011). }\end{array}$ \\
\hline 1952 & $\begin{array}{l}\text { Eruption propelling an ash column up to } \sim 1000 \mathrm{~m} \text { from the summit. Eruption sound was heard in } \\
\text { Tobelo (15 km from volcano) (Data Dasar, 2011). }\end{array}$ \\
\hline 1969 & $\begin{array}{l}\text { Eruption building ash column. The explosion was heard at Galela (10 km from summit) (Data Dasar, } \\
\text { 2011). }\end{array}$ \\
\hline 1971 & $\begin{array}{l}\text { Eruption building up a black column of ash up to } 300 \mathrm{~m} \text { from summit. Ash fall at the summit (Data } \\
\text { Dasar, 2011). }\end{array}$ \\
\hline 1978-1979 & $\begin{array}{l}\text { Explosions of varying strength occurred about once every } 10 \text { seconds, ejecting bombs as large as } 4 \\
\mathrm{~m} \text { up to } 200-250 \mathrm{~m} \text { from the crater rim. Ash emission was nearly continuous, with clouds rising as } \\
\text { high as } 10 \mathrm{~km} \text { above the crater. Ash was blown North beyond the Galela, } 15 \mathrm{~km} \text { from the volcano. } \\
\text { From Galela incandescent ejecta were visible (GVP, 1978. Report on Dukono (Indonesia)). }\end{array}$ \\
\hline Jun. 1991 & $\begin{array}{l}\text { Eruption generation ash column up to } 1500 \mathrm{~m} \text { above crater rim. Ash fall witnessed on Tobelo, lava } \\
\text { glow seen at the summit at night whilst lahar occurred following the eruption (Data Dasar, 2011). }\end{array}$ \\
\hline May 1992 & Eruption building up ash plume to $400 \mathrm{~m}$ above volcano (Data Dasar, 2011). \\
\hline Nov.-Dec. 1993 & $\begin{array}{l}\text { Eruption building up ash plume up to } 300-600 \mathrm{~m} \text { above summit (Data Dasar, 2011). The cloud was } \\
\text { rising up to } 600-1500 \mathrm{~m} \text { (GVP, 1993. Report on Dukono (Indonesia)). }\end{array}$ \\
\hline Jan., Sep. 1995 & $\begin{array}{l}\text { Eruption generating ash fall but weather condition didn't allow detail observation (Data Dasar, } \\
\text { 2011). }\end{array}$ \\
\hline Mar. - Dec. 2003 & $\begin{array}{l}\text { Eruption building up ash plume to } 200-500 \mathrm{~m} \text { above summit. Ash fall witnessed at Tobelo (Data } \\
\text { Dasar, 2011). }\end{array}$ \\
\hline 2004-2005 & Continuous ash emission (GVP, 2006. Report on Dukono (Indonesia). \\
\hline 2006 - present & $\begin{array}{l}\text { Intermittent ash emission with variable discharge intensity. In } 2007 \text { and } 2014 \text { the ash plume was } \\
\text { clearly observed by MODIS (GVP, 2007. Report on Dukono (Indonesia) }\end{array}$ \\
\hline
\end{tabular}


Table 2.

\begin{tabular}{|c|c|c|c|}
\hline & $13 / 07 / 2015$ & $08 / 09 / 2015$ & Average \\
\hline \multicolumn{4}{|l|}{ Gas concentration } \\
\hline Mean $\mathrm{SO}_{2}(p p m$ v) & $5.3 \pm 1.3$ & $2.0 \pm 0.5$ & $3.6 \pm 0.9$ \\
\hline Mean $\mathrm{H}_{2} \mathrm{~S}(\mathrm{ppm} \mathbf{v})$ & $0.2 \pm 0.05$ & $0.2 \pm 0.04$ & $0.2 \pm 0.04$ \\
\hline Mean $\mathrm{CO}_{2}(\mathrm{ppm}$ v) & $362 \pm 90$ & $400 \pm 100$ & $381 \pm 95$ \\
\hline Mean $\mathbf{H}_{2}(\mathbf{p p m}$ v) & $2 \pm 0.5$ & $1.0 \pm 0.2$ & $1.5 \pm 0.7$ \\
\hline Mean $\mathrm{H}_{2} \mathrm{O}(\mathbf{p p m}$ v) & $9000 \pm 2200$ & $8000 \pm 2000$ & $8500 \pm 2100$ \\
\hline $\mathrm{H}_{2} \mathrm{O} / \mathrm{SO}_{2}$ & $60.5 \pm 19.1$ & $61.2 \pm 22.1$ & $60.8 \pm 20.6$ \\
\hline $\mathrm{CO}_{2} / \mathrm{SO}_{2}$ & $0.4 \pm 0.1$ & $0.6 \pm 0.2$ & $0.5 \pm 0.1$ \\
\hline $\mathrm{H}_{2} \mathrm{~S} / \mathrm{SO}_{2}$ & $0.03 \pm 0.01$ & $0.05 \pm 0.02$ & $0.03 \pm 0.01$ \\
\hline $\mathrm{H}_{2} / \mathrm{SO}_{2}$ & $0.3 \pm 0.1$ & $0.1 \pm 0.07$ & $0.2 \pm 0.09$ \\
\hline \multicolumn{4}{|c|}{ Gas composition and flux estimates } \\
\hline & Composition (mol \%) & Flux $\left(\mathrm{t} \mathrm{d}^{-1}\right)$ & \\
\hline $\mathrm{H}_{2} \mathrm{O}(\mathrm{mol} . \%)$ & $97.2 \pm 2.7$ & $14000 \pm 4000$ & \\
\hline $\mathrm{SO}_{2}(\mathrm{~mol} . \%)$ & $1.6 \pm 0.4$ & $819 \pm 235$ & \\
\hline $\mathrm{CO}_{2}(\mathrm{~mol} . \%)$ & $0.8 \pm 0.2$ & $242 \pm 69$ & \\
\hline $\mathrm{H}_{2} \mathrm{~S}$ (mol. \%) & $0.06 \pm 0.01$ & $13 \pm 4$ & \\
\hline $\mathrm{H}_{2}(\mathrm{~mol} . \%)$ & $0.30 \pm 0.07$ & $7 \pm 2$ & \\
\hline
\end{tabular}


Table 3.

280

\begin{tabular}{|c|c|c|c|c|c|}
\hline $\begin{array}{c}\text { Start Time } \\
\text { (LT) } \\
\text { (date: Jul. 12, 2015) }\end{array}$ & $\begin{array}{l}\text { End Time } \\
\quad \text { (LT) }\end{array}$ & $\begin{array}{l}\text { Number of } \\
\text { Spectra }\end{array}$ & $\begin{array}{c}\text { Scanning step } \\
\left({ }^{\circ}\right)\end{array}$ & $\begin{array}{c}\text { Mean Column } \\
\text { Amount (ppm.m) }\end{array}$ & $\mathrm{SO}_{2}$ flux (t/d) \\
\hline $11: 11: 41$ & $11: 14: 46$ & 76 & 1.8 & 474 & $756 \pm 220$ \\
\hline $11: 14: 46$ & $11: 16: 32$ & 76 & 1.8 & 619 & $992 \pm 229$ \\
\hline $11: 17: 52$ & $11: 22: 48$ & 76 & 1.8 & 359 & $778 \pm 223$ \\
\hline $11: 24: 03$ & $11: 28: 31$ & 76 & 1.8 & 325 & $1044 \pm 289$ \\
\hline $11: 28: 41$ & $11: 32: 57$ & 76 & 1.8 & 534 & $530 \pm 162$ \\
\hline $11: 33: 10$ & $11: 37: 58$ & 76 & 1.8 & 496 & $549 \pm 170$ \\
\hline 11:38:08 & $11: 43: 20$ & 76 & 1.8 & 1059 & $902 \pm 255$ \\
\hline $11: 43: 30$ & $11: 48: 44$ & 76 & 1.8 & 1270 & $834 \pm 243$ \\
\hline 11:51:59 & $11: 57: 14$ & 76 & 1.8 & 452 & $1707 \pm 470$ \\
\hline $11: 57: 27$ & $12: 02: 28$ & 78 & 1.8 & 642 & $2015 \pm 541$ \\
\hline $12: 02: 38$ & $12: 06: 24$ & 76 & 1.8 & 589 & $745 \pm 211$ \\
\hline $12: 06: 34$ & 12:11:06 & 76 & 1.8 & 613 & $937 \pm 265$ \\
\hline $12: 11: 17$ & $12: 16: 48$ & 76 & 1.8 & 332 & $804 \pm 237$ \\
\hline $12: 16: 59$ & $12: 21: 14$ & 76 & 1.8 & 347 & $576 \pm 163$ \\
\hline $12: 21: 25$ & $12: 26: 13$ & 76 & 1.8 & 392 & $510 \pm 155$ \\
\hline $12: 26: 22$ & $12: 30: 40$ & 76 & 1.8 & 564 & $413 \pm 124$ \\
\hline $12: 30: 50$ & $12: 35: 26$ & 76 & 1.8 & 362 & $553 \pm 164$ \\
\hline $12: 35: 37$ & $12: 41: 08$ & 76 & 1.8 & 446 & $922 \pm 274$ \\
\hline $12: 48: 12$ & $12: 53: 22$ & 76 & 1.8 & 446 & $569 \pm 177$ \\
\hline $13: 27: 15$ & $13: 32: 07$ & 76 & 1.8 & 465 & $444 \pm 137$ \\
\hline
\end{tabular}


Table 4.

\begin{tabular}{|c|c|c|c|c|c|c|c|c|c|c|c|c|c|c|c|}
\hline \multicolumn{16}{|c|}{ Bulk composition } \\
\hline & \multicolumn{2}{|c|}{$\begin{array}{c}\text { Fresh ash (Jul } \\
\text { 2015) }\end{array}$} & $\begin{array}{c}\text { Fresh ash } \\
\text { (Sep 2015)_1 }\end{array}$ & $\begin{array}{c}\text { Fresh ash } \\
\text { (Sep 2015)_2 }\end{array}$ & Layer A & Layer B & Layer C & $\underset{\text { D }}{\text { Layer }}$ & $\begin{array}{c}\text { Layer } \\
1\end{array}$ & $\begin{array}{l}\text { Layer } \\
2\end{array}$ & $\begin{array}{c}\text { Layer } \\
3\end{array}$ & $\begin{array}{c}\text { Layer } \\
4\end{array}$ & $\begin{array}{c}\text { Layer } \\
5\end{array}$ & $\begin{array}{l}\text { Layer } \\
\quad 6\end{array}$ & $\begin{array}{c}\text { Layer } \\
7\end{array}$ \\
\hline $\mathrm{SiO}_{2}(\mathrm{wt} \%)$ & \multicolumn{2}{|c|}{58.0} & 59.5 & 59.3 & 59.0 & 58.9 & 58.9 & 58.9 & 59.4 & 59.2 & 58.4 & 59.6 & 59.0 & 59.4 & 58.7 \\
\hline $\mathrm{TiO}_{2}$ & \multicolumn{2}{|c|}{0.8} & 0.8 & 0.7 & 0.7 & 0.7 & 0.7 & 0.7 & 0.7 & 0.7 & 0.8 & 0.7 & 0.7 & 0.7 & 0.7 \\
\hline $\mathrm{Al}_{2} \mathrm{O}_{3}$ & & & & 15.8 & 14.5 & 14.2 & 14.1 & 14.2 & 14.3 & 14.3 & 13.5 & 14.4 & 14.2 & 14.5 & 15.0 \\
\hline $\mathrm{Fe}_{2} \mathrm{O}_{3}$ & & & & 8.6 & 9.4 & 9.9 & 10.1 & 1.0 & 9.4 & 9.5 & 11.2 & 9.2 & 9.8 & 9.1 & 9.0 \\
\hline MnO & & & & 0.1 & 0.1 & 0.1 & 0.2 & 0.2 & 0.2 & 0.1 & 0.2 & 0.1 & 0.1 & 0.1 & 0.1 \\
\hline MgO & & & & 2.3 & 2.2 & 2.7 & 2.6 & 2.6 & 2.1 & 1.9 & 3.5 & 2.1 & 2.6 & 2.0 & 1.8 \\
\hline $\mathrm{CaO}$ & & & & 6.0 & 6.8 & 6.4 & 6.6 & 6.5 & 6.5 & 6.7 & 6.4 & 6.4 & 6.5 & 6.6 & 7.0 \\
\hline $\mathrm{Na}_{2} \mathrm{O}$ & & & & 3.5 & 3.3 & 3.3 & 3.3 & 3.3 & 3.3 & 3.4 & 3.3 & 3.4 & 3.4 & 3.3 & 3.5 \\
\hline $\mathbf{K}_{2} \mathbf{O}$ & & & & 2.5 & 3.3 & 3.1 & 3.2 & 3.2 & 3.4 & 3.5 & 3.0 & 3.3 & 3.2 & 3.4 & 3.3 \\
\hline $\mathbf{P}_{2} \mathbf{O}_{5}$ & & & & 0.3 & 0.4 & 0.4 & 0.4 & 0.3 & 0.4 & 0.4 & 0.3 & 0.4 & 0.4 & 0.4 & 0.3 \\
\hline $\mathrm{SO}_{3}$ & & & & - & 0.0 & 0.0 & 0.0 & 0.0 & 0.1 & 0.1 & 0.1 & 0.1 & 0.1 & 0.0 & 0.0 \\
\hline Total & & & & 99.1 & 99.7 & 99.7 & 100.1 & 90.9 & 99.8 & 99.8 & 100.7 & 99.7 & 100 & 99.5 & 99.4 \\
\hline Melt inclusi & & & & & & & & & & & & & & & \\
\hline & ol-1 & ol-1 & cpx-1 & cpx-2 & & igio-1 & plagio-2 & & plagio-3 & plagio-4 & plagio-5 & & plagio-6 & plagio- & \\
\hline $\mathrm{SiO}_{2}(\mathrm{wt} \%)$ & 52.9 & 52.5 & 50.8 & 55.1 & 59 & & 60.0 & & 60.3 & 61.0 & 61.9 & & 63.0 & 64.2 & \\
\hline $\mathrm{TiO}_{2}$ & 0.7 & 0.6 & 0.7 & 0.6 & 1. & & 0.8 & & 0.9 & 0.9 & 0.8 & & 0.9 & 0.8 & \\
\hline $\mathrm{Al}_{2} \mathbf{O}_{3}$ & 18.5 & 18.0 & 17.2 & 16.5 & 14 & & 15.1 & & 14.8 & 14.8 & 14.5 & & 14.9 & 14.9 & \\
\hline $\mathrm{FeO}$ & 6.3 & 6.6 & 9.1 & 5.8 & 8. & & 7.4 & & 7.9 & 7.4 & 7.3 & & 7.0 & 6.1 & \\
\hline MnO & 0.0 & 0.2 & 0.3 & 0.2 & 0. & & 0.1 & & 0.2 & 0.2 & 0.1 & & 0.1 & 0.1 & \\
\hline MgO & 3.1 & 4.4 & 4.5 & 4.1 & 2. & & 2.3 & & 2.1 & 2.3 & 2.0 & & 1.4 & 1.4 & \\
\hline $\mathrm{CaO}$ & 9.7 & 9.4 & 8.9 & 7.8 & 4. & & 4.8 & & 4.5 & 4.7 & 4.3 & & 4.1 & 3.7 & \\
\hline $\mathrm{Na}_{2} \mathrm{O}$ & 3.2 & 3.1 & 2.7 & 2.8 & 3. & & 3.5 & & 3.8 & 3.7 & 3.7 & & 3.8 & 3.9 & \\
\hline $\mathrm{K}_{2} \mathbf{O}$ & 1.4 & 1.3 & 0.7 & 1.3 & 3. & & 2.9 & & 3.2 & 3.1 & 3.4 & & 3.4 & 3.6 & \\
\hline $\mathbf{P}_{2} \mathbf{O}_{5}$ & 0.3 & 0.2 & 0.2 & 0.2 & 0. & & 0.4 & & 0.5 & 0.7 & 0.4 & & 0.5 & 0.4 & \\
\hline Total & 96.2 & 96.4 & 95.0 & 94.4 & 97 & & 97.4 & & 98.3 & 98.8 & 98.5 & & 99.3 & 99.0 & \\
\hline $\mathrm{H}_{2} \mathrm{O}(\mathrm{wt} \%)$ & 3.8 & 3.6 & 5.0 & 5.6 & 2. & & 2.6 & & 1.7 & 1.2 & 1.5 & & 0.7 & 0.9 & \\
\hline $\mathrm{Cl}$ (ppm) & 741.0 & 720.0 & 576.0 & 780.0 & & & 1178.0 & & 1065.0 & 960.0 & 974.0 & & 1230.0 & 1050.0 & \\
\hline $\mathbf{F}$ & 200.0 & 190.0 & 178.0 & 173.0 & & & 540.0 & & 626.0 & 536.0 & 699.0 & & 359.0 & 226.0 & \\
\hline $\mathbf{S}$ & 1120.0 & 1090.0 & 1119.0 & 1100.0 & & & 240.0 & & 307.0 & 395.0 & 228.0 & & 289.0 & 287.0 & \\
\hline $\mathbf{L i}(\mathbf{p p m})$ & $<4.7$ & 11.2 & 29.9 & 49.8 & 83 & & 57.3 & & 21.2 & 55.7 & 19.5 & & 24.3 & 20.8 & \\
\hline $\mathbf{v}$ & 269.2 & 259.3 & 361.7 & 293.9 & & & 213.0 & & 171.7 & 157.9 & 154.5 & & 146.2 & 93.7 & \\
\hline $\mathrm{Cr}$ & 41.5 & 49.9 & $<8.7$ & 12.5 & $<7$ & & $<9.1$ & & $<6.9$ & $<6.5$ & $<8.7$ & & $<9.2$ & $<6.8$ & \\
\hline Co & 21.3 & 21.0 & 29.8 & 19.5 & 22 & & 19.5 & & 16.3 & 18.1 & 18.5 & & 15.1 & 11.9 & \\
\hline $\mathbf{N i}$ & 14.8 & 14.1 & 12.2 & 10.6 & 5. & & 7.1 & & 3.7 & 4.8 & 4.3 & & 5.3 & 5.6 & \\
\hline $\mathbf{R b}$ & 25.2 & 24.4 & 9.7 & 12.3 & 67 & & 40.5 & & 49.6 & 55.7 & 52.7 & & 62.8 & 58.5 & \\
\hline $\mathrm{Sr}$ & 476.3 & 469.3 & 354.1 & 466.6 & & & 282.7 & & 255.7 & 283.1 & 254.1 & & 273.8 & 234.2 & \\
\hline $\mathbf{Y}$ & 15.7 & 15.0 & 21.5 & 11.9 & 40 & & 21.1 & & 29.4 & 31.1 & 21.3 & & 33.9 & 34.7 & \\
\hline $\mathbf{Z r}$ & 60.5 & 59.9 & 51.0 & 47.1 & & & 83.1 & & 117.6 & 132.5 & 86.4 & & 152.4 & 159.2 & \\
\hline Nb & 0.9 & 0.9 & 0.6 & 0.7 & 3. & & 1.3 & & 1.8 & 2.1 & 1.4 & & 2.4 & 2.4 & \\
\hline Ba & 213.9 & 214.1 & 116.3 & 165.6 & & & 365.5 & & 406.3 & 432.6 & 404.0 & & 463.0 & 534.5 & \\
\hline La & 6.7 & 6.7 & 8.0 & 6.7 & 15 & & 8.7 & & 11.6 & 13.4 & 10.2 & & 15.1 & 14.9 & \\
\hline $\mathrm{Ce}$ & 15.0 & 14.6 & 19.5 & 15.9 & 37 & & 19.3 & & 27.2 & 30.3 & 21.7 & & 32.7 & 33.5 & \\
\hline Nd & 9.6 & 9.4 & 12.1 & 9.0 & 24 & & 12.7 & & 18.8 & 19.8 & 14.3 & & 21.6 & 21.4 & \\
\hline Sm & 2.3 & 2.5 & 2.8 & 1.9 & 6. & & 3.4 & & 4.3 & 5.1 & 3.5 & & 5.8 & 5.3 & \\
\hline Eu & 0.8 & 0.7 & 1.0 & 0.7 & 1. & & 1.0 & & 1.2 & 1.4 & 1.2 & & 1.6 & 1.5 & \\
\hline Gd & 2.9 & 2.6 & 3.0 & 1.9 & 6. & & 3.2 & & 4.5 & 5.5 & 3.6 & & 6.0 & 5.9 & \\
\hline $\mathbf{Y b}$ & 1.6 & 1.7 & 2.5 & 1.5 & 4. & & 2.6 & & 3.2 & 3.0 & 2.2 & & 3.6 & 4.0 & \\
\hline Lu & 0.3 & 0.3 & 0.4 & 0.2 & 0. & & 0.4 & & 0.5 & 0.5 & 0.3 & & 0.5 & 0.6 & \\
\hline $\mathbf{P b}$ & 6.6 & 6.4 & 3.9 & 4.5 & 14 & & 11.5 & & 11.5 & 11.7 & 11.8 & & 15.3 & 14.0 & \\
\hline Th & 1.0 & 1.0 & 0.5 & 0.5 & 3. & & 1.4 & & 2.1 & 2.3 & 1.4 & & 2.6 & 2.6 & \\
\hline
\end{tabular}


Figure 1.

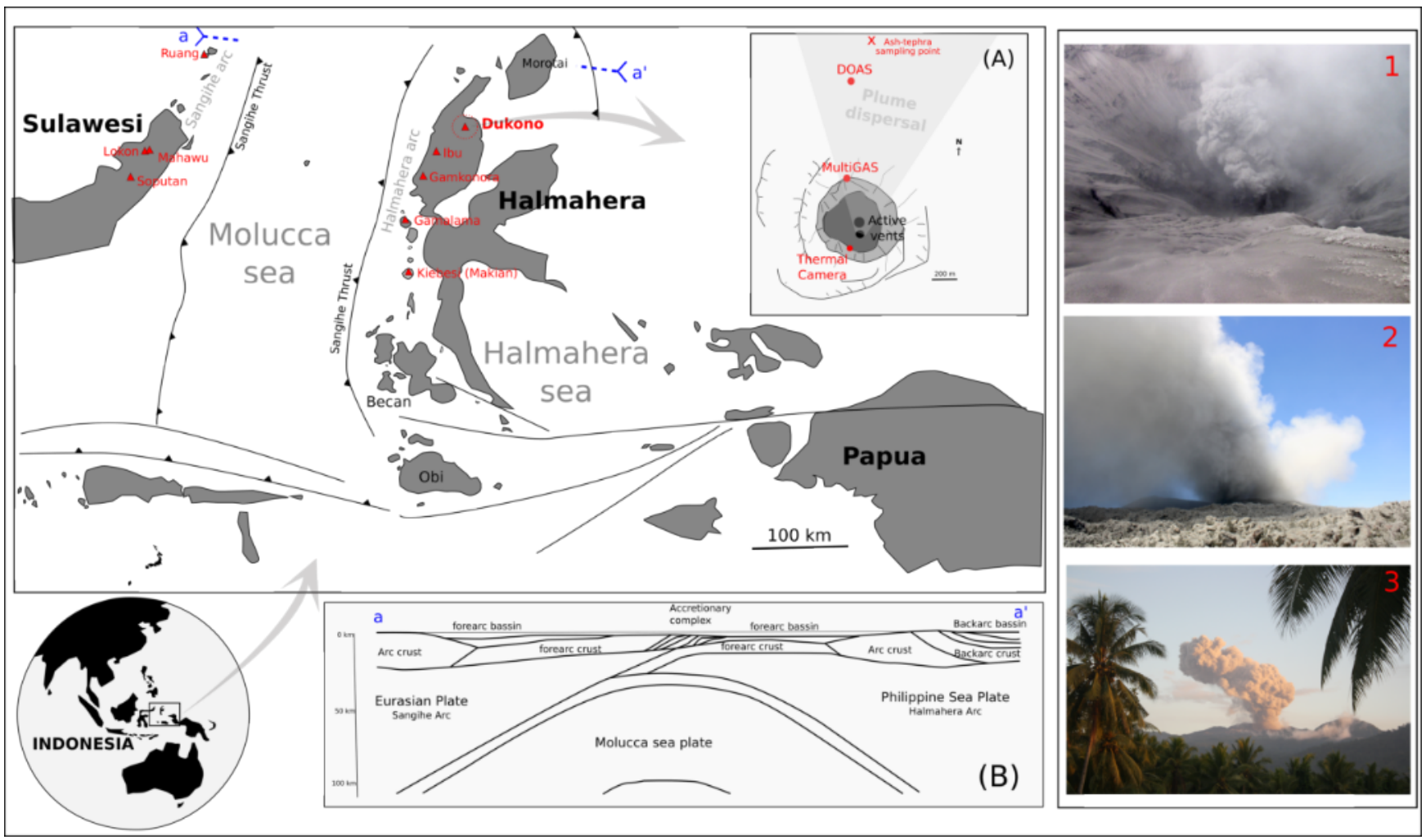


Figure 2.

295

300
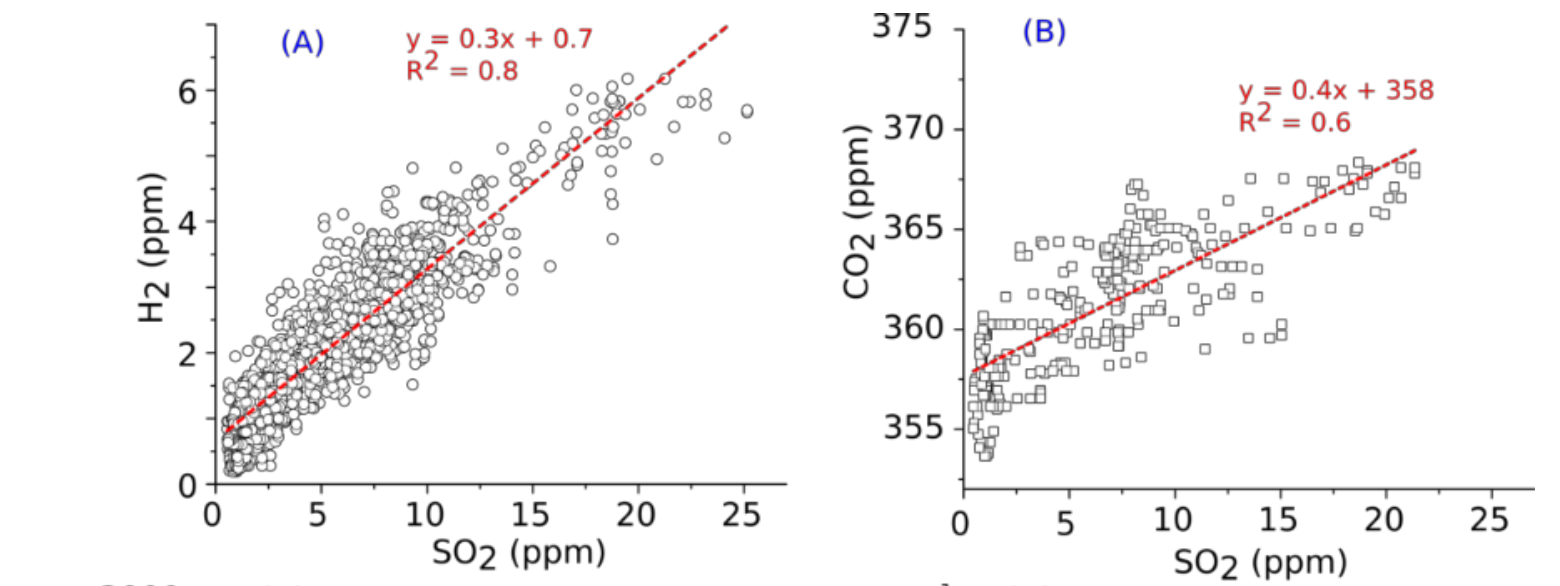

305
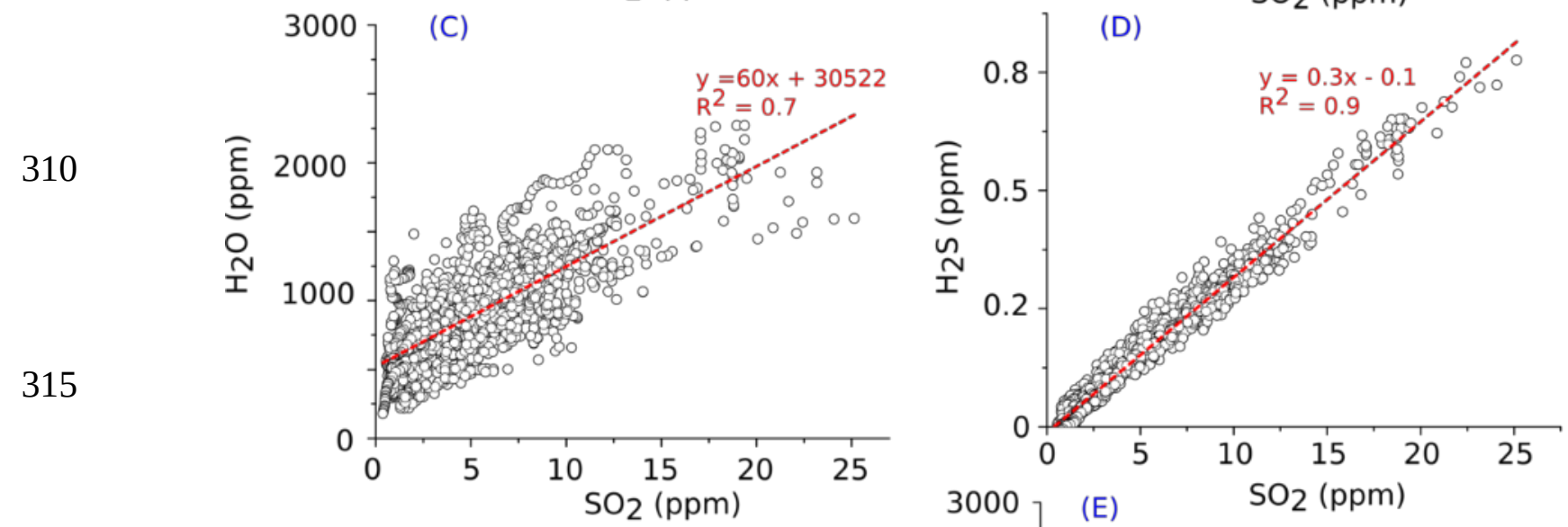

320

310

315

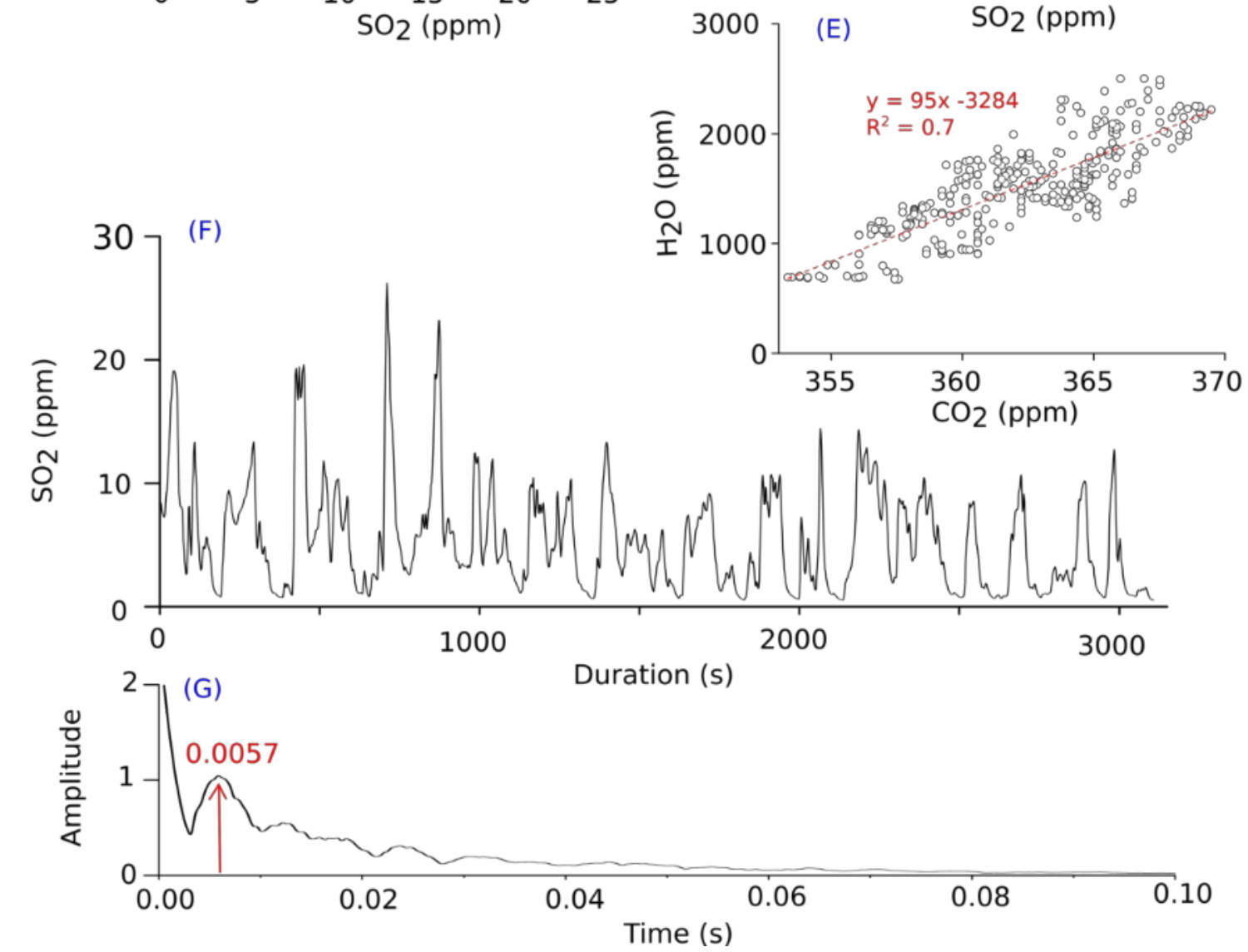

325

330

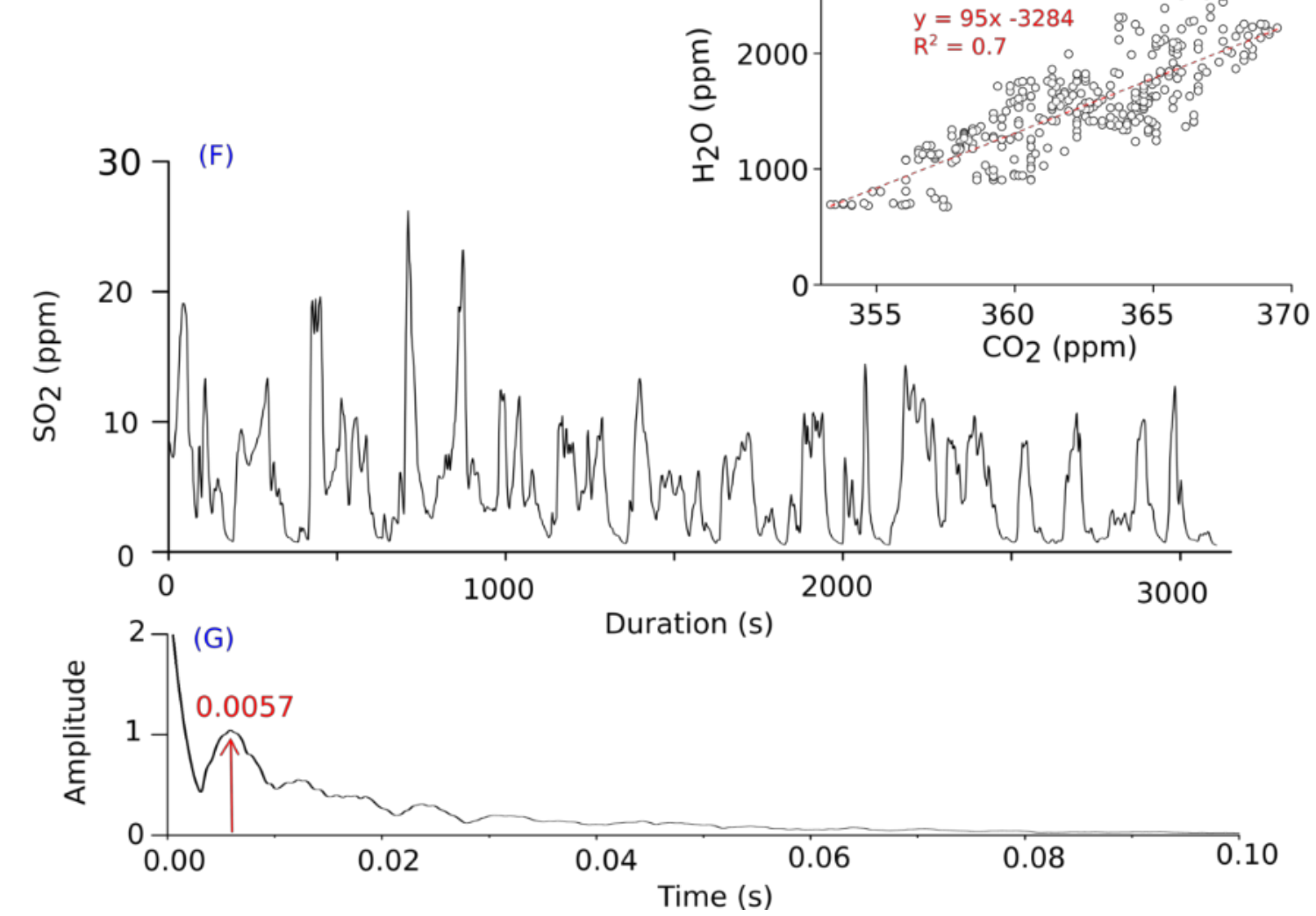

335

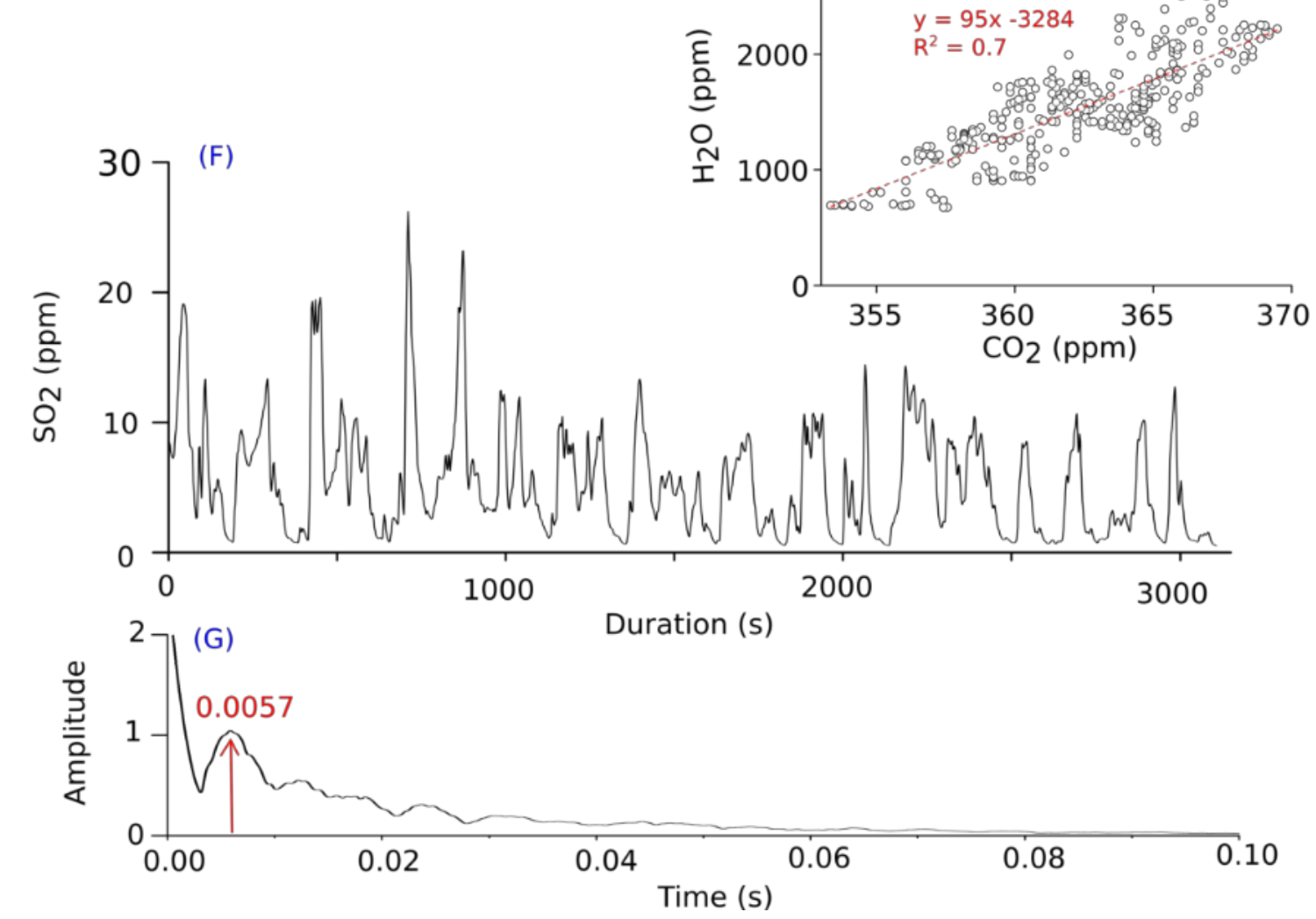


Figure 3.

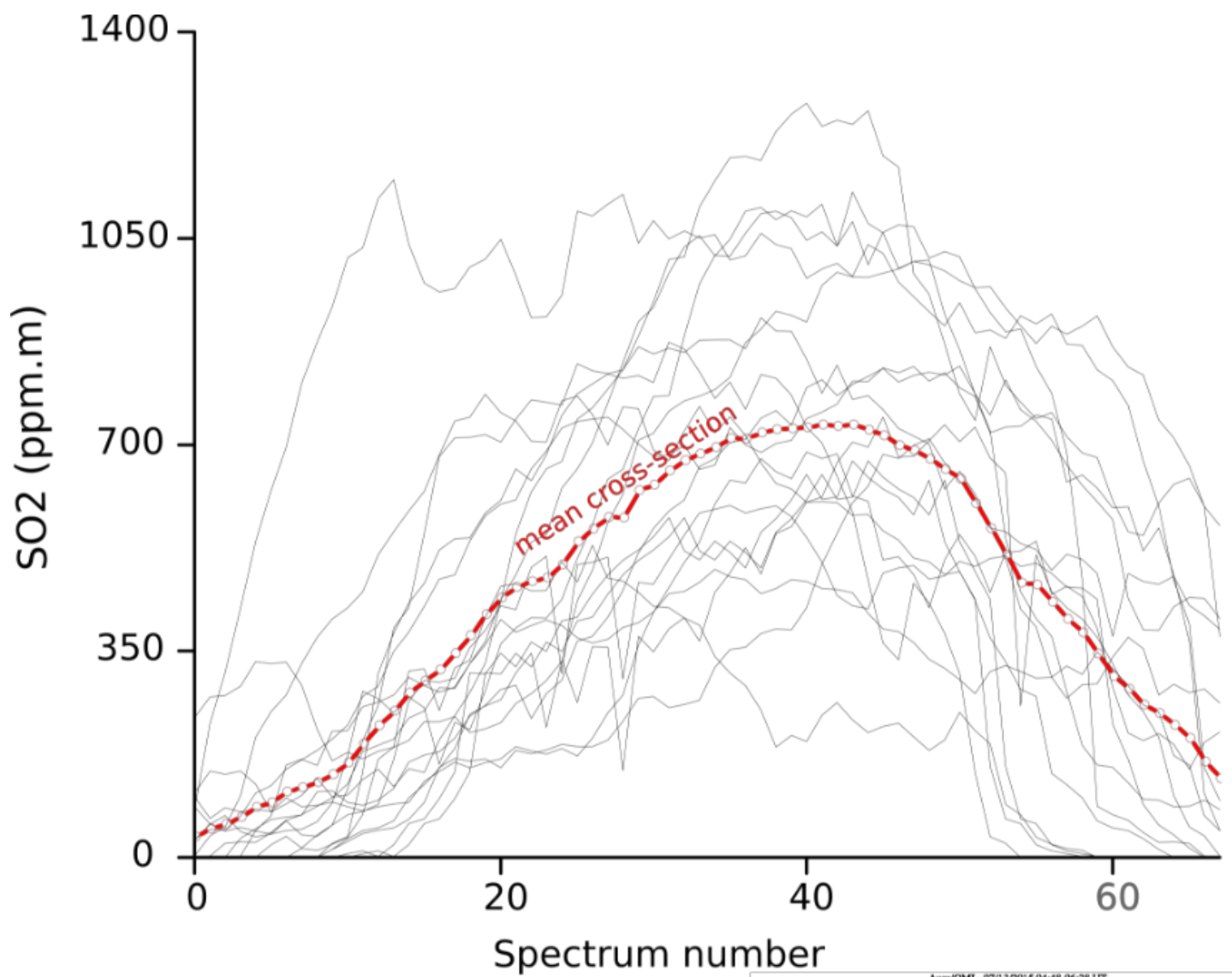

350

355

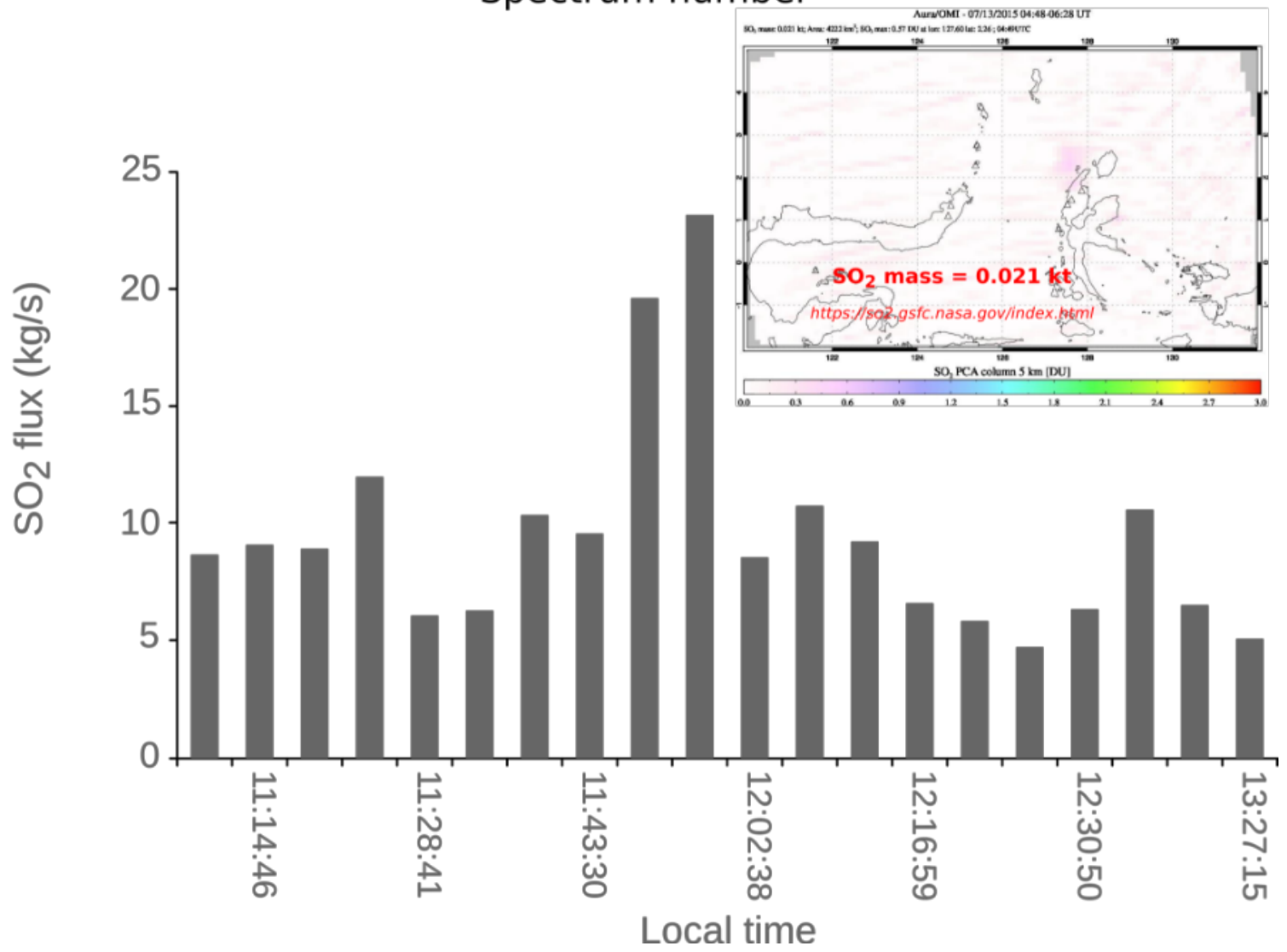


Figure 4.
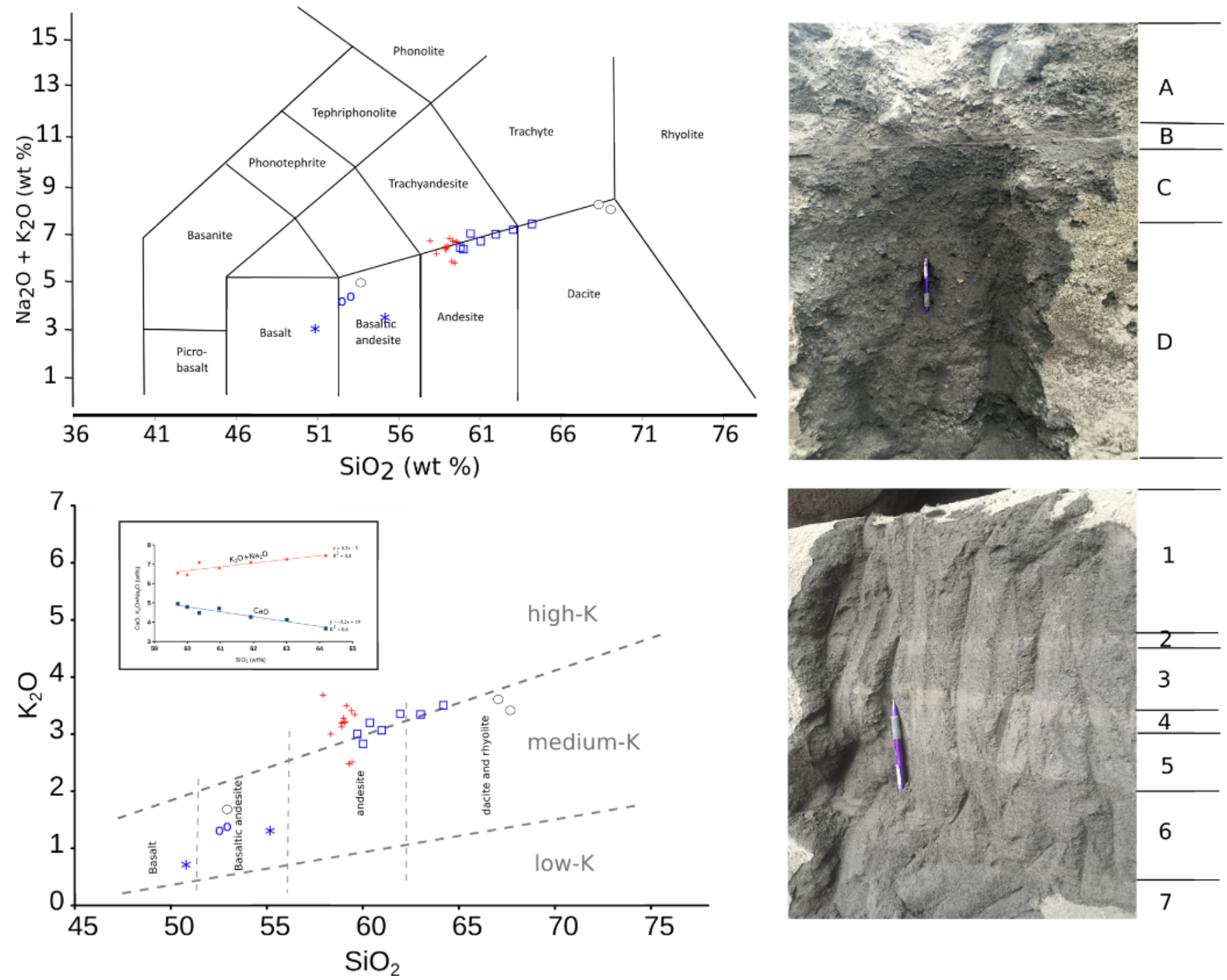
Figure 5.

365
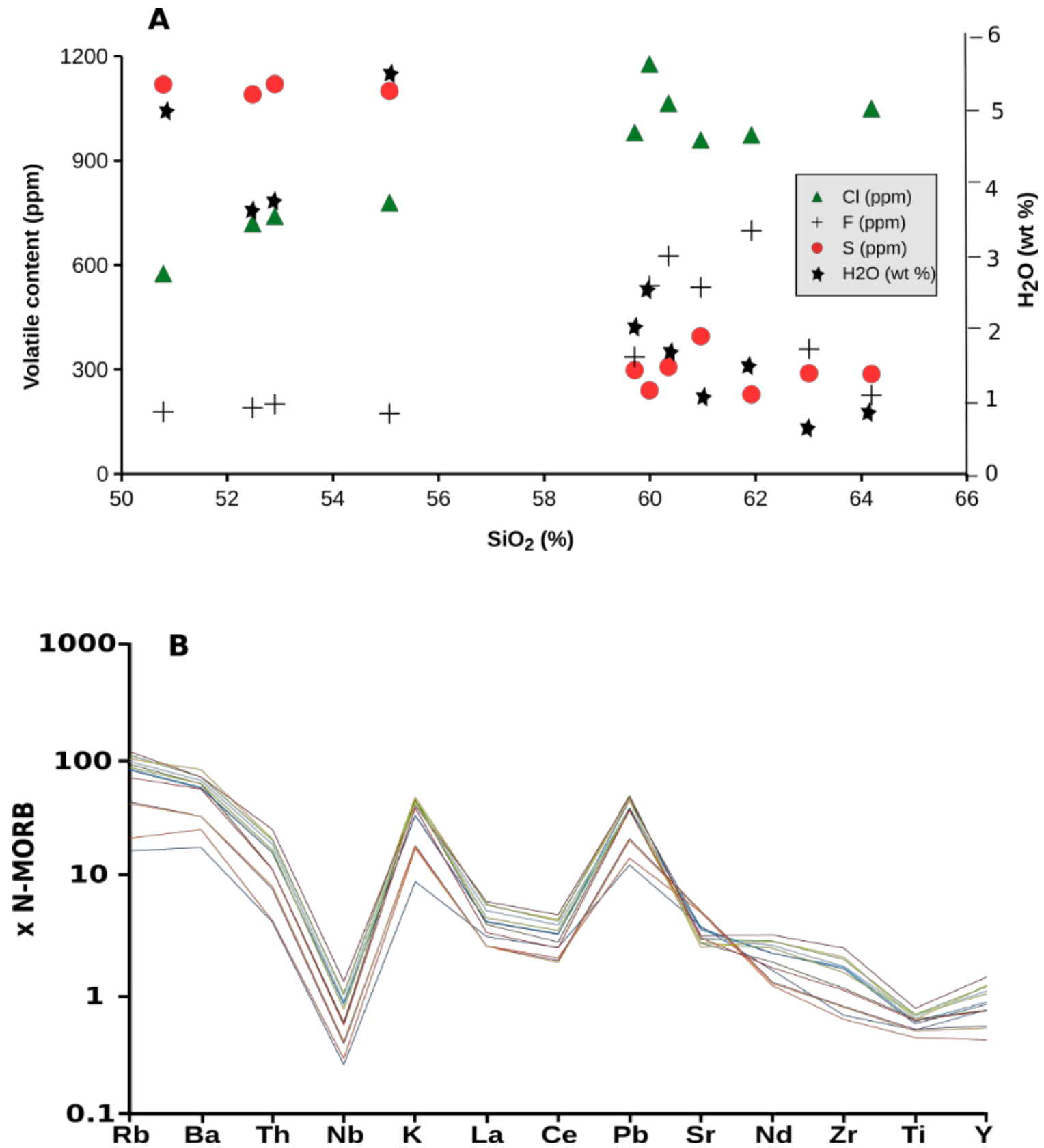
Figure 6.
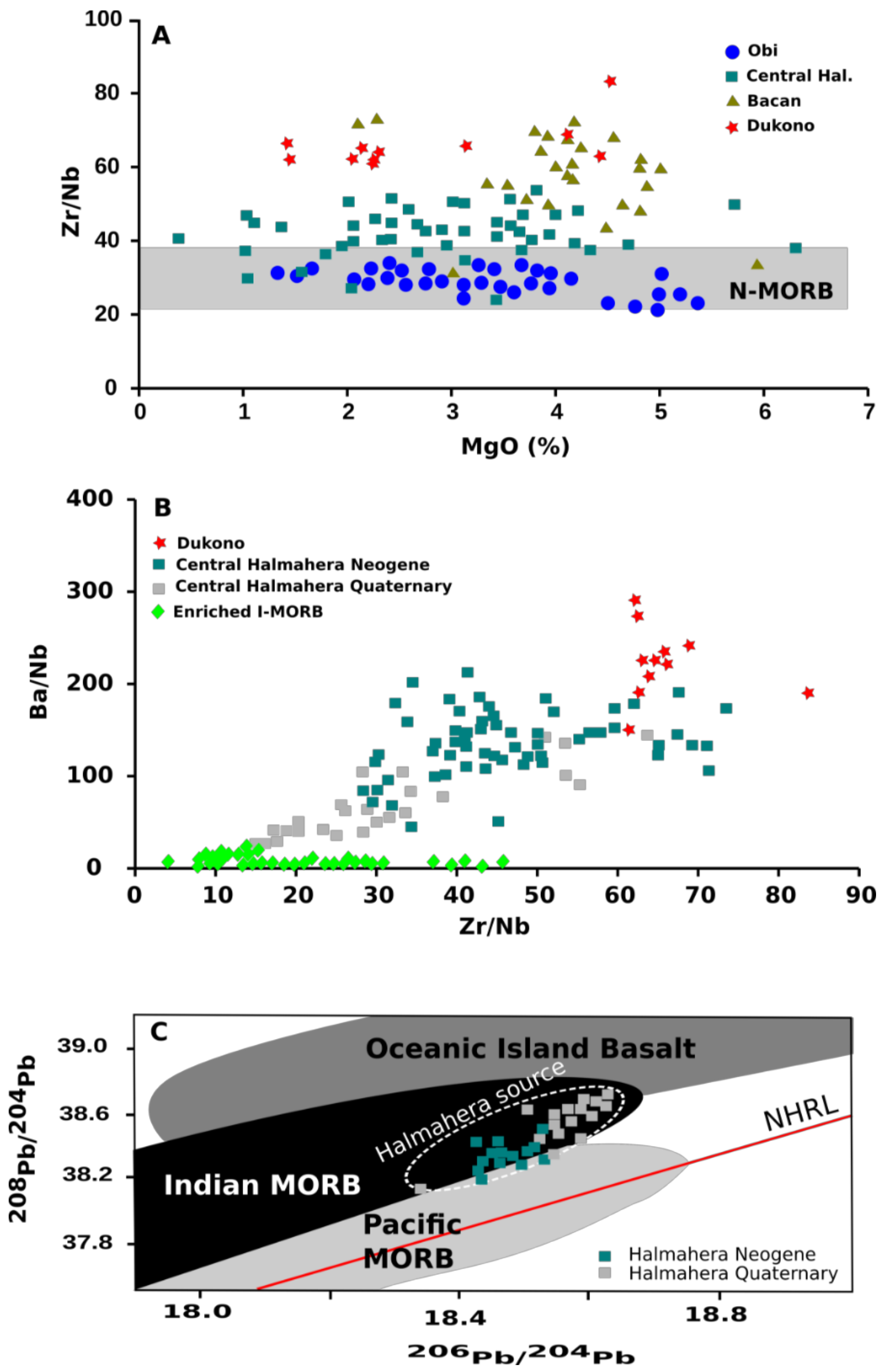